HNO 2021 · 69:338-365

https://doi.org/10.1007/s00106-021-01046-9

Accepted: 6 March 2021

Published online: 13 April 2021

(c) The Author(s) 2021

\author{
Albert Mudry' $\cdot$ Robert Mlynski ${ }^{2} \cdot$ Burkhard Kramp $^{2}$ \\ 'School of Medicine, Department of Otolaryngology, Head \& Neck Surgery, Stanford University, Stanford, \\ USA \\ ${ }^{2}$ Klinik und Poliklinik für Hals-Nasen-Ohrenheilkunde, Kopf- und Halschirurgie "Otto Körner", \\ Universitätsmedizin Rostock, Rostock, Germany
}

\title{
History of otorhinolaryngology in Germany before 1921
}

Prior to the late nineteenth century, individual clinical disciplines were named after the organ they focused on. The term "otology" appears to have come into use in the mid-seventeenth century, with the Greek term otologia. The term "rhinology" appeared nearly a century later, first in English, and the term "laryngology" three decades later in the eighteenth century, first in French [3]. In the 1890s, the term "otolaryngology" appeared in French and the term "otorhinolaryngology" in Spanish to progressively become widely used. The association of ORL with head and neck surgery was a mid-1960s event.

In 1875, Isambert and colleagues stated: "Specialties are, in fact, one of the requirements, and we could also add, one of the real methods of progress in modern science. In medicine, as is the same everywhere, the division of labor has become a necessity. The time of acknowledgeable scholars is gone... Those organs that are not directly accessible to our senses are becoming one by one more accessible thanks to exploratory instruments ... In conjunction with the diseases of the larynx, we are always obliged to describe those of the pharynx, the nasal fossa and of the mouth ... For these different diseases, there is a common ground" [4]. Everything was a question of mucosa!

\section{Background}

Otorhinolaryngology went through three chronological phases:

- creation in the second part of the nineteenth century;
- consolidation in the first part of the twentieth century, which concerns the period of study; and

- expansion since the second part of the twentieth century $[5,6]$.

The first phase of the history of ORL, creation, was marked by the foundation of the first ORL hospital departments and university lectures and chairs, the organization of the first specific national and international congresses, and the publication of the first ORL journals and books. According to Isambert et al., "The close anatomical and pathological relations existing between the ear, the nose and the throat often render it necessary that diseases of those organs be treated by the same hand" [4]. The second phase, consolidation, was particularly marked by the recognition of ORL as a medical specialty and its obligatory teaching during medical studies. Special training was organized to obtain the title of ORL specialist.

The aim of this article is to present the main German inventions and advances, but also the academic organizations that preceded and led to the creation of the German Society of Otorhinolaryngology, Head and Neck Surgery in 1921. The limitations of this study are associated with manuscript length restrictions, and perhaps with the impossibility of studying in detail all the places in Germany where ORL was practiced during this period. Another limitation is that the article will not present a complete and chronological history of ORL, but only particular facts.

The text is divided into three main sections: history of ORL in Germany un- 
Hier steht eine Anzeige.

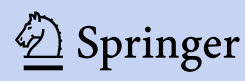


til the beginning of the nineteenth century, focusing mainly on the development of knowledge; the birth of the subspecialties otology, laryngology (pharyngolaryngology and endoscopy), and rhinology in the nineteenth century, combining the advancement of knowledge and implementation of academic structures; and the creation of the specialty ORL at the turn of the twentieth century, mainly concentrated on academic organization and expansion.

\section{Methodology}

\section{Literature search}

The first stage of research was to look for similar publications. Since the midtwentieth century, the history of otorhinolaryngology, head and neck surgery (OHNS) became a subject of interest with two main levels of research: a universal overview of ORL history and its subspecialties [7, 8], and a more specific ORL national view. Two partial ORL histories were published in Germany: a 1989 publication dealing with the history of rhino-laryngology [9], and a 2003 publication compiling more than 30 historical articles related to different and particular aspects of the history of ORL [10]. There are hardly any specific details on the history of ORL in Germany until 1921 in these two textbooks. Nevertheless, they contain many relevant but dispersed details about German protagonists. Only one valuable chapter about a part of this history was found in Die Entwicklung der medizinischen Spezialfächer an den Universitäten des deutschen Sprachgebietes (The Development of Medical Specialties in the Universities of German-Speaking Countries) published in 1970 [11]. Concerning otology in Germany, specifically, a paper published in 1902 [12] and a chapter published in 1913 [13] were found. Two other German publications are of general interest, but of very limited use because they collect almost only twentieth century documentation about the academic ORL chairs [14] and ORL clinics [15] in Germany. Other more focused books are available, dealing with the history of ORL notably in Berlin [16], Munich [17],
Würzburg [18], Düsseldorf [19], BerlinWedding [20], and Rostock [21]. A few specific chapters are also found in books dealing with the history of some German universities.

To complete these sources, at least six biographies of German physicians were found: those of Hermann von Helmholtz [22], Gustav Killian [23, 24], Friedrich Hofmann [25], Anton von Tröltsch [26], Otto Körner [27], who also published his autobiography [28], and Johannes Kessel [29]. Confronted with this paucity of publications, a second level of research was thus necessary to find additional related papers, again with not much success. Very few articles were usable, notably one dealing with the origin of the first German ORL clinics [30]. This situation explains why it was important to study this period, but also the difficulty in collecting the best available material. It can also explain why some facts are certainly missing.

\section{History of ORL until the beginning of the 19th century}

During the first steps of development of ORL, knowledge was scattered throughout many different countries without a truly progressive line of advancement in one specific country, with some exceptions as exemplified by the main advances made in ORL anatomy in the sixteenth century in Italy. Thus, to better understand the development of ORL knowledge in Germany until the beginning of the nineteenth century, it is necessary to consider it in an overview of the general ORL history during the same period. It is outside the scope of this research to go into detail, and therefore we highlight some of the main points only [31].

\section{》) The history of ORL is as old as medicine itself}

The history of ORL is certainly as old as medicine itself. The first medical writings found in ancient civilizations demonstrated that the symptoms were the diseases, such as painful tongue, face ecchymosis, ear that heard badly, ear that gave water of decomposition, tumefaction of the neck, swelling in the throat, fetid nose, or exudate in the nose. The enumeration of symptoms was a fundamental step in the comprehension of the disease. Physical examination was limited to external observation and palpation, except inside the mouth. Treatments were purely empirical, based on remedies of vegetal, mineral, and animal origin, for example: oil, fat, honey, sea salt, cumin, beer foam, date wine, boiled hedgehog's thorns, rat head, fly specks, human bone, red ground ochre, mercury, copper, arsenic, and malachite. Some surgical methods, mainly in relation to trauma, were used, such as sutures, digital reposition of the nose, as well as reconstruction of the lobes of the ear and nose with flaps. Extraction of foreign bodies from the ear, excision of the uvula, incision of throat abscesses, and nose tamponade were also mentioned.

\section{The Ancient Greek and Roman world}

The Ancient Greek world introduced the concept that diseases were not supernatural but had a natural origin, and based on the Hippocratic theory of the four humors, each one could be insufficient or excessive. Thus, it introduced new therapies based on purgation (emetics, clysters, bloodletting, and cupping), cauterization, fumigation, modification of the ambient environment, and diet. Another important concept that influenced ORL until modern times was the idea that effusions of the ear and the nose were excretions of the brain.

The Roman world improved on humoral theory and added the concept of "disease of the parts"-i.e., organic origin of disease, as an example from the ear or the larynx. Anatomy was very superficial and saw its first descriptions, mainly based on animal studies. Many new words were introduced to name different parts, notably for the auricle, the cartilage of the nose and larynx, and the muscles of the larynx. The external auditory canal ended with a "dry thin-spun web," the hidden part of the ear was simply named "labyrinth," and the windpipe the "trachea-arteria." Certain surgical tech- 
niques were clearly exposed, such as: the extraction of foreign bodies in the ear with a hook, an ear-spoon, or "auricular clyster"; the ablation of nasal polyps with a special knife or a sponge attached to a string passed into the nose, to forcibly draw the polyp from its attachment; the ablation of tonsils with a finger, or with a hook and a scalpel; and the sectioning of the uvula. From the first century BC, the opening of the trachea was clearly discussed under different appellations, such as "laryngotomy," "cutting the larynx," "incision of the arteria," or "pharyngotomy." At the same time, the first pharmacopoeia was published, which listed more than 1000 remedies, mainly plants, but also minerals and products of animal origin.

\section{The Middle Ages}

The Middle Ages did not bring much innovation, except for some surgical instruments and the idea of a kind of "cold which arises during spring when roses deploy their perfume." The first known bivalve ear and the first nose speculum for extracting a foreign body from the external auditory canal were described in 1368: "You may be able to expose him to the sunlight by tugging the ear to dilate it with a speculum" [32]. Bedside examination, essentially represented by anamnesis and superficial physical examination, remained definitively fundamental in the initial approach to OHNS diseases. It was refined during subsequent developments in ORL.

\section{The Renaissance and early Modern Age}

The Renaissance and early Modern Age (sixteenth to eighteenth centuries) opened new fields in medicine, mainly in anatomy and pathology. Human dissection became possible, thus leading to the progressive description of all the macroscopic parts of the body with the introduction of numerous new terms such as "tympanic membrane," "cochlea," "maxillary antrum," or the proper use of other terms such as "cricoid cartilage." In particular, the nasal turbinates, the four sinuses of the face with their orifices, the

HNO 2021 -69:338-365 https://doi.org/10.1007/s00106-021-01046-9

(c) The Author(s) 2021

\section{A. Mudry $\cdot$ R. Mlynski $\cdot$ B. Kramp}

\section{History of otorhinolaryngology in Germany before 1921}

\section{Abstract}

In 2021, the German Society of Otorhinolaryngology, Head and Neck Surgery is celebrating the 100th anniversary of its foundation. The aim of this article is to present the main inventions and progress made in Germany before 1921, the date the society was founded. Three chronological periods are discernible: the history of otorhinolaryngology (ORL) in Germany until the beginning of the 19th century, focusing mainly on the development of scattered knowledge; the birth of the sub-specialties otology, laryngology (pharyngo-laryngology and endoscopy), and rhinology in the 19th century, combining advances in knowledge and implementation of academic structures; and the creation of the ORL specialty at the turn of the 20th century, mainly concentrating on academic organization and expansion. This period was crucial and allowed for the foundation of the German Society of Otorhinolaryngology, Head and Neck Surgery on solid ground. Germany played an important role in the development and progress of ORL internationally in the 19th century with such great contributors as Anton von Tröltsch, Hermann Schwartze, Otto Körner, Rudolf Voltolini, and Gustav Killian to mention a few.

\section{Keywords}

Otolaryngology · Anniversaries and special events · Societies · Endoscopy · Medical specialties

\section{Geschichte der Hals-Nasen-Ohrenheilkunde in Deutschland vor 1921}

\section{Zusammenfassung}

Im Jahr 2021 feiert die Deutsche Gesellschaft für Hals-Nasen-Ohren-Heilkunde, Kopf- und Hals-Chirurgie den 100. Jahrestag ihrer Gründung. Ziel der vorliegenden Arbeit ist es, die wesentlichen Erfindungen und Fortschritte darzustellen, die vor 1921, dem Jahr, in welchem die Gesellschaft gegründet wurde, in Deutschland gemacht wurden. Es lassen sich 3 chronologische Phasen unterscheiden: die Geschichte der HalsNasen-Ohren-Heilkunde in Deutschland bis zu Beginn des 19. Jahrhunderts, wobei der Schwerpunkt v. a. auf der Fortentwicklung des verstreut vorhandenen Wissens lag; die Geburtsstunde der Subspezialisierungen Otologie, Laryngologie (Pharyngolaryngologie und Endoskopie) und Rhinologie im 19. Jahrhundert, in dem die Wissensfortschritte mit der Implementierung akademischer Strukturen kombiniert wurden; und die Entstehung des Fachgebiets der Hals-Nasen-
Ohren-Heilkunde zu Beginn des 20. Jahrhunderts, in dem man sich hauptsächlich auf die akademische Organisation und Expansion konzentrierte. In dieser entscheidenden Phase wurde die Gründung der Deutschen Gesellschaft für Hals-Nasen-Ohren-Heilkunde, Kopf- und Hals-Chirurgie auf einer tragfesten Grundlage möglich. Deutschland spielte bei der Entwicklung und dem Fortschritt der HalsNasen-Ohren-Heilkunde international im 19. Jahrhundert eine bedeutende Rolle mit solch großartigen Mitwirkenden wie Anton von Tröltsch, Hermann Schwartze, Otto Körner, Rudolf Voltolini und Gustav Killian, um nur einige zu nennen.

\section{Schlüsselwörter}

Otolaryngologie - Jahrestage und spezielle Ereignisse - Gesellschaften · Endoskopie · Medizinische Fachgebiete three ear ossicles, the tympanic cavity, the vestibule, the semicircular canals, the cochlea, the detailed anatomy of the larynx, and the cranial nerves were described. The salivary glands were elegantly depicted with their respective excretory canals. Saliva was demonstrated to originate not from the lymph, as suspected before, but from these glands.

Johann Friedrich Cassebohm (16991743) from Halle/S. published an anatomical work on the organ of hearing, notably its embryonic part, which became the reference until the mid-nineteenth century. The accompanying drawings were the best for their time [33]. A second 
step was made with the introduction of the simple microscope, leading to the description of most of the details of the inner ear, and the confirmation that it is filled with fluid and not air as supposed since antiquity. The anatomist Philipp Friedrich Theodor Meckel (1756-1803) in Halle/S. added new details to the description of the aqueducts of the inner ear [34].

\section{1) Human dissection became possible during the 16th-18th centuries}

By the end of the seventeenth century, knowledge of the gross anatomy of the larynx was complete. There remained the addition of details of the nerve supply [35] and structure of the epithelial lining. In 1797, the anatomist Carl Samuel Andersch (1732-1777) from Göttingen posthumously published an elegant dissection of the laryngeal nerves. He displayed each of the branches of the recurrent laryngeal nerves and attributed no muscular branches to the superior laryngeal nerve, with the exception of one to the cricothyroid muscle. He traced filaments of the nerve to the mucous membrane. His name is eponymously associated with the petrosal ganglion of the glossopharyngeal nerve [36].

Physical examination expanded with the detailed study of the external auditory canal and the nostrils rendered possible with the bivalve speculum, notably improved by the Germanborn surgeon Guilhelmus Fabry von Hilden (1560-1634), commonly known as Hildanus. $\mathrm{He}$ is considered one of the first surgeons to recognize the importance of anatomy in the practice of surgery and of medicine in general, anatomy being "at once the key and the rudder of medicine." He demonstrated this in publishing an anatomical treatise in 1624 [37]. He had a great genius for observation and his collection of 500 surgical observations published between 1606 and 1627 was the best work of its kind in the seventeenth century [38]. He notably described an ear speculum [39] and a snare for uvulectomy.
Reconstructive surgery was advanced with the improvement of flaps, particularly for the nose and the ears, and the use of prosthesis for the same parts. Tracheostomy (a term introduced at the beginning of the seventeenth century), even if not very popular, involved different techniques being performed with a vertical, horizontal, or punctiform opening, associated with the placement of a canula. The advent of pathology and the understanding of the local lesions related to the disease made it clear that defluxion of the nose and the ears came from these respective parts and not from the brain as thought since antiquity. Konrad Victor Schneider (1614-1680) from Bitterfeld played a key role, when he wrote that, "catarrhal matter is not an excrement from the brain, but a bloody mass" [40] and originated from the inflamed organ. He studied the origin of nasal discharge to definitively demonstrate that it originates from the anteroposterior pituitary membranes, i.e., the nasal mucosa. The Schneiderian membrane, also called the "Schneiderian epithelium," the lining of the paranasal sinuses and nasal cavity, is named after him. He showed that, in fact, no fluid from the viscosity of mucus was present in the cranial cavity. Concerning ear catarrh, he also demonstrated its origin in the ear, although this was not accepted in his time, but only nearly a century later. He mentioned for the first time the adenoid: "It is of a whitish color, the adjoining membranes being bloody or dusky. It is fuller than they and like fat. It is always moist and exudes a glutinous substance" [40, 41].

\section{I) Hildanus was one of the first surgeons to recognize the importance of anatomy}

Günther Christoph Schelhammer (16491712) from Jena was the first to decisively and unequivocally take the stand that "genuine air" had no physiological significance. He argued that it could not be the "instrument of hearing" because sound was conducted by air and the medium itself could not be the sense organ, just as the lens of the eye, or vitreum, is not itself the organ of visual perception. Al- though he opposed the idea of "genuine air" and considered the auditory nerve as indispensable to hearing, he obscured his theory with the then popular concept of "animal spirit," which he believed necessary for the process of hearing: "The nerve by itself has nothing to do with the perception of sound, and it could certainly be absent if this so-named animal spirit was not required for the knowledge of species [i.e. sensations] of hearing" [42]. In another passage, Günther Christoph Schelhammer wrote that: "If for example a knife or a two-pronged fork, which we use to eat, are strongly struck against the wood of a table, so that the iron shakes, and we approach the other end to the teeth, we will perceive a sound in a very elegant and very clear manner. But if we introduce it completely into the mouth, we perceive nothing." It appears that Günther Christoph Schelhammer was probably the first to have recognized the excellent vibratory properties of forks and employed them for experimental purposes before the invention of the tuning fork in 1711 .

At the same time, the surgeon Johannes Scultetus (1595-1645) from Ulm published a surgical book that had many editions and translations into different languages. He notably described the dangers associated with using an ear syringe. Antique surgeries were slightly improved and new ones were introduced: the opening of the maxillary sinus in the case of infection through three different routes-the canine fossa, the tooth, and the nasal wall of the maxillary sinus; the superficial opening of the mastoid area in the case of abscess as soon as fluctuation was felt with the trephine, or gouge and mallet, rugine, or a perforator; the catheterization of the Eustachian tube first through the mouth then through the nose with a "silver tube" in the case of obstruction of "external and internal auditory passages"; and the perforation of the tympanic membrane "with a sharp, long, but small lancet," in the case of deafness. The surgeon Justus Arnemann (1763-1806) from Göttingen published the first textbook dealing exclusively with the perforation of the mastoid process in 1792 [43]. Pain, bleeding, and infection 
Hier steht eine Anzeige.

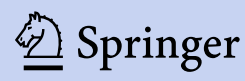



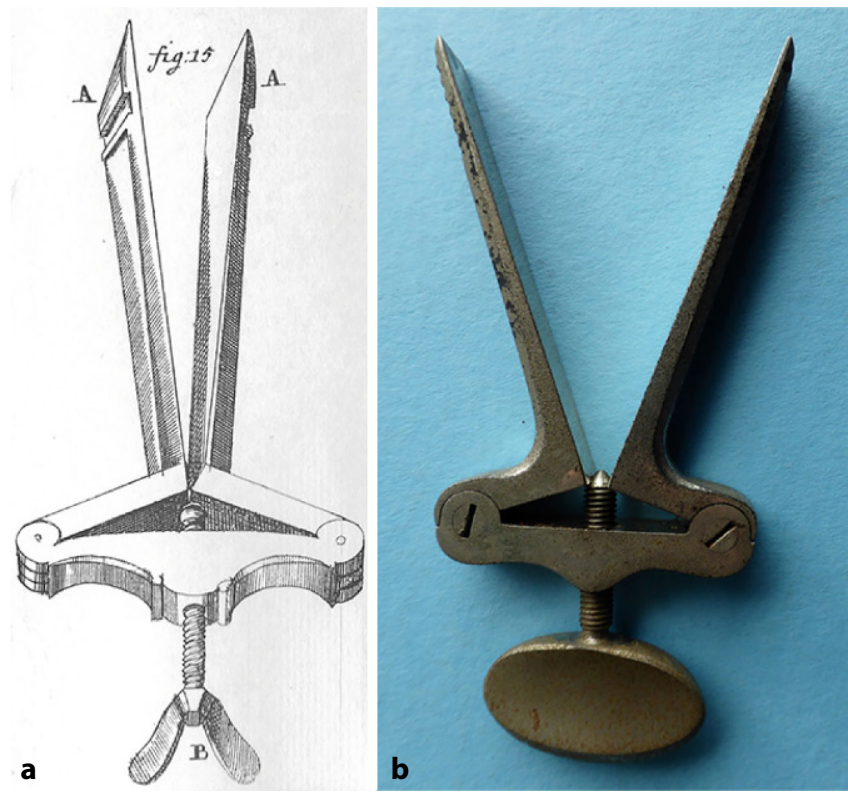

Fig. $1<$ Heister mouth gap. a Heister's textbook, tab. XIII, p. 532 bis [46]; b personal collection, Dr. Lübbers. (Reprinted with permission @ W. Lübbers, Hannover, all rights reserved) were the limiting factors of surgical interventions.

The major, sometimes endemic and not infrequently fatal, throat condition was suffocative angina and ulcerations, sometimes with false membrane, later grouped under the name "diphtheria" [44]. The first to discuss deviations of the nasal septum appears to have been the anatomist and surgeon Samuel Theodor Quelmaltz (1696-1758) from Leipzig, who published an essay in Latin in 1750 entitled "On the Nose and Its Septal Bendings" [45]. He considered the causes of obstruction to be pressure on the nose in a difficult labor, falls in infancy, the continual thrust of the finger into the nose in childhood, and inflammatory conditions. He did not discuss treatment of the condition, which was not considered until the following century.

I) Pain, bleeding, and infection were the limiting factors of surgical interventions

The surgeon Lorenz Heister (1683-1758) in Helmstedt wrote a general review of surgery first in 1719 [46], which also had many editions and translations. $\mathrm{He}$ described numerous instruments such as a mouth gap (• Fig. 1). He developed a surgical technique to correct "nose holes glued against nature." He also proposed using a lead or silver cannula placed in the nose to maintain it in case of fracture. Ludolf Heinrich Runge (1727-1756) from Bremen wrote a dissertation on diseases of the frontal sinus, maxillary sinus, and to some extent the mandible. He described an almost perfect systematics of the diseases of the paranasal sinuses, and proceeded from Konrad Schneider's knowledge that the nose and the paranasal sinuses are lined by the same mucous membrane to conclude that any inflammation of the nasal mucosa can spread to the sinuses and lead to an accumulation of pus there. Treatment should then be drainage of the affected cavity [47].

Deaf-mute children were no longer considered as "burdensome pariahs," and their systematic education was of public concern and established with two main controversial approaches, i.e., oralism and manualism. The systematic and methodical education of deaf-mute individuals began in Germany with Samuel Heinicke (1729-1790; [48]). In 1778 he founded the first institute for instructing deaf-mute people in Leipzig and directed it until his death. Heinicke's methods were strictly oral. First, the pupil had to learn to take in with their eyes the meaning of what a person said, then when they understood the thought, they could be taught the various forms and symbols in which speech was expressed. Surprisingly, Heinicke never described his method in detail in his publications, but indulged in general considerations that did not give sufficient clues to his methodology. Nosologies were implemented in an attempt to classify the different known diseases, thus introducing new terms, such as "otitis" and "epistaxis."

Otology began to be a separate topic [49] with the publication of its own books, the first in German by Christian Friedrich Ludwig Wildberg (1765-1850) from Neustrelitz (at the time Neuenstrelitz), in 1795 [50]. It was one of the first comprehensive textbooks on diseases of the ear in German. The results and discoveries in previous specialized publications, and the works of foreign authors that were difficult to obtain, were put together to form a well-organized whole. The book was divided into three parts: anatomy, physiology, and pathology.

At the turn of the nineteenth century, anatomo-pathology was implemented and completed the progress made in anatomy.

\section{The development of subspecialties}

\section{Laying the foundation}

\section{Examination techniques and instrumentation}

The first part of the nineteenth century was marked by clinico-experimentation, which progressively completed bedside examination in the understanding of ORL diseases. It made it possible to make more precise diagnoses, thus rendering specific therapy more efficient. It opened up a new approach in medical practice with the correlation of the bedside clinical symptoms and the lesions described during autopsy. Anamnesis became more orientated and more precise. A second, later step was added with the possibility of investigating the quality of the different liquids and secretions of the body in the laboratory, and also the microscopic structures of the tissues (biopsies).

New examination techniques with novel definitive instruments were in- 
troduced to directly find these lesions. The funnel-shaped speculum was finally accepted, the laryngeal mirror and the bivalve nasal speculum found their definitive shape rendering physical examination more objective. These three instruments precluded the development of the three subspecialties of otology, laryngology, and finally rhinology. The first ORL journal-after specialized otology journals were founded more than a decade earlier-was published in 1875 in French (Annales des maladies de l'oreille et du larynx) with the subtitle "otoscopy, laryngoscopy, rhinoscopy" [51].

\section{Cell theory}

Before going into more detail about these emerging subspecialties, some other overall aspects must be presented. The development of cell theory, and thereby the demonstration that most diseases were linked to cellular troubles, and that the ear, nose, and larynx have a similar lining in most of their parts (i.e., respiratory mucosa), led to the concept of a common insight in the development of these diseases. A clear relationship was demonstrated, directing physicians to join together in the care of the diseases of these organs and to create the ORL specialty. At the same time, physiological experiments began to be conducted to understand the functions of the ORL organs.

\section{Advances in surgery}

Up until the first part of the nineteenth century, surgery did not really progress and remained very limited. Some already described operations were demonstrated as being dangerous such as mastoidectomy. Other interventions became very popular. Clinico-experimentation reinforced anatomo-pathology for optimalquality diagnostics.

In the first part of the nineteenth century, a new era of surgery commenced, which developed further in the second part of the century. The invention of anesthesia with ether and chloroform in the 1840s and the introduction of asepsis (sterilization), antisepsis (disinfection), and arterial clamps in the 1860s ushered in a completely new surgical era in the second part of the nineteenth century with the possibility to operate for more than only a few minutes and with fewer surgical complications. New operating rooms were created. In parallel, medication for pain relief was developed (morphine, salicin), thus, rendering postoperative care more successful and affordable for the patients. With all these surgical possibilities, ORL rapidly became a surgical specialty. New techniques were progressively introduced allowing for more precise surgery.

The discovery of bacteria as agents responsible for the development of infection was another important event. Concomitantly, local anesthesia with cocaine was introduced in 1884 [52]. It opened a new field of "minor" operations notably in the larynx and the nose. In the second part of the nineteenth century, diphtheria remained a fatal condition. The idea to pass an oral tube into the trachea to relieve airway obstruction $[53,54]$ represented another solution for treating this condition. This gave birth to modern intubation for general anesthesia. Tuberculosis, notably of the larynx, was another matter of concern. Specialized catalogues of instruments completed the first textbooks dealing with ORL.

\section{Role of radiology}

At the turn of the twentieth century, the discovery of X-rays modified the practice of ORL. Radiology made it possible to look directly inside the ORL cavities of the face leading to the development of numerous different approaches to specifically analyze the ear, the sinus, and the larynx. The development and evolution of cancer are better understood in the ORL region, including the evaluation of primary local metastases as a part of diagnosis and treatment. Radiology also enabled the detection of swallowed or aspirated foreign bodies in the airways and esophagus. Radiotherapy (Röntgen therapy) was introduced, such as radium therapy. Radium therapy was promptly stopped because of its many side effects. All these developments found a specific place in the progress of the ORL subspecialties.

\section{Otology}

Often combined with ophthalmology, otology became a specialty in the first decades of the nineteenth century, notably with the opening of the first ear polyclinics and the growing number of published books dealing exclusively with the ear. First in the United Kingdom and in France, this movement took place in Germany from the 1830s [55]. Two German protagonists played an important role: Wilhelm Kramer (1801-1875) from Berlin and Carl Gustav Lincke (1804-1849) from Leipzig. For more than 40 years Kramer worked on otology and published many textbooks. His main textbook, Die Erkenntniss und Heilung der Ohrenkrankheiten (The $\mathrm{Na}$ ture and Treatment of Diseases of the Ear; [56]), translated into French and English, saw three expanded editions. His publications occupy a special place in the otology literature of the nineteenth century. His main contribution was that the treatment of ear diseases should not depend on symptomatology, but on clinical examination of the ear. This led to a new era in otology, and prompted the development of otoscopy. However, he was a fervent adversary of pathological anatomy, and engaged with his colleagues in a very long saga of conflict. "What good work Dr. Kramer actually did for otology in his younger days has been overshadowed by his subsequent writings [...] He still persists in rejecting the modern method of investigation, as well as the results of examinations of ears removed from persons who have been deaf" [57]. His name is also eponymously associated with an ear speculum (- Fig. 2).

Lincke published a comprehensive and well-illustrated work on otology entitled a Handbuch der theoretischen und praktischen Ohrenheilkunde (Handbook of Theoretical and Practical Otology) in three volumes between 1837 and 1845 [58]. Only the first two were written by Lincke. Illness forced him to transfer the writing of the third volume to the German otologist Philip Heinrich Wolff (1813-1886) from Berlin. He completed his otology publication with the five-volume Sammlung auserlesener $A b$ - 

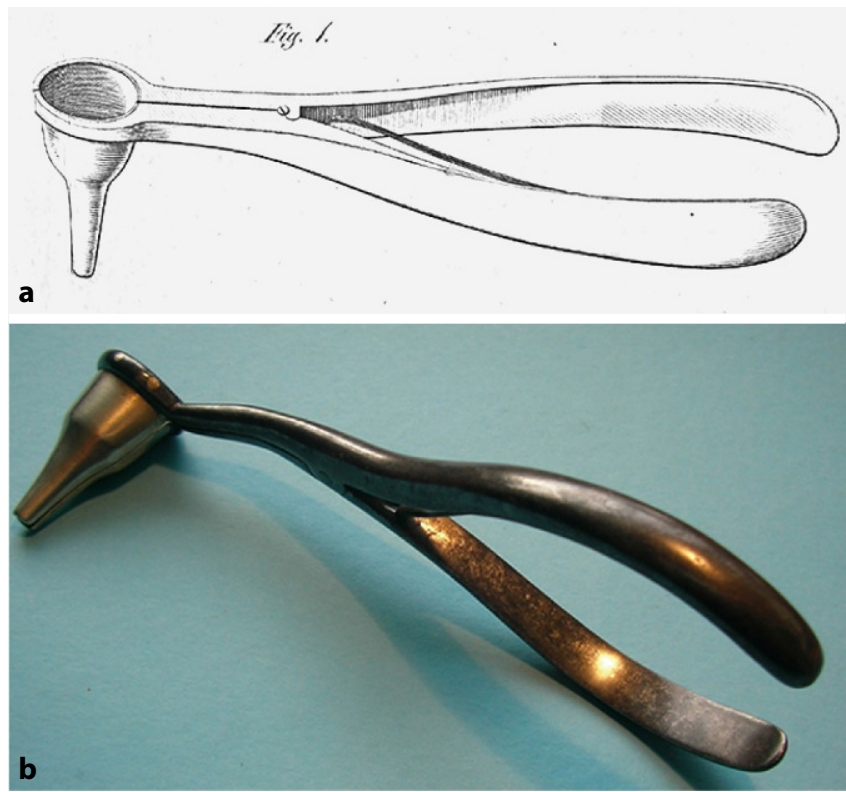

Fig. $2 \Delta$ Kramer's ear speculum. a from Kramer's textbook (1836, [56]); b personal collection, Dr. Lübbers. (Reprinted with permission $\odot$ W. Lübbers, Hannover, all rights reserved)

handlungen und Beobachtungen aus dem Gebiete der Ohrenheilkunde (Compilation of Chosen Essays and Observations from the Area of the Diseases of the Ear), in which he assembled many important otology works published in the second part of the eighteenth and essentially in the first part of the nineteenth century [59]. He translated texts not originally written into German language. Gustav Lincke's approach contrasted sharply with that of Wilhelm Kramer, who was very critical of Gustav Lincke's views [60]. In his comprehensive work, he carefully collected the achievements of previous otologists, attempting to save them from falling into oblivion. However, he also recognized new achievements. This was a period when historical medical studies were considered a waste of time and when Kramer declared with authority that there was nothing to be gained from studying the pathological anatomy of the ear. Gustav Lincke's tireless enthusiasm for studying old literature therefore deserves special recognition. His handbook will always remain a valuable source for the historian. It "comprises all that was known upon the subject of aural surgery at the time in which it was written" [61]. In 1845 , he developed a specific device to avoid rapid closure of the artificial tympanic perforation. Gustav Lincke explained that "the most suitable solution here is to insert a small rubber tube, with one end being so slim, that it could be inserted into the opening of the tympanic membrane. The tube is shaped to become gradually wider, and its other end is the same width as the opening of the external auditory canal" (• Fig. 3; [58]) The tube was as long as the external auditory canal and its external part had a curved border to remain fastened to the tragus. In the same year, Martell Frank (1810-1886) of Munich presented another such device [62]. They were the first tympanostomy tubes that became popular only in the second part of the twentieth century [63].

To better understand the place occupied by German ear physicians in the development of otology as a specialty, it is better to follow a clinical chronology. The anatomy of the ear was improved with the use of the compound microscope, and physiology of the ear by the possibility to experiment. In 1778, the German anatomist Samuel Thomas Soemmerring (1755-1830) proposed separating the cranial nerves into 12 pairs, and to differentiate the facial and auditory nerves by giving them two different numbers, seven for the facial and eight for

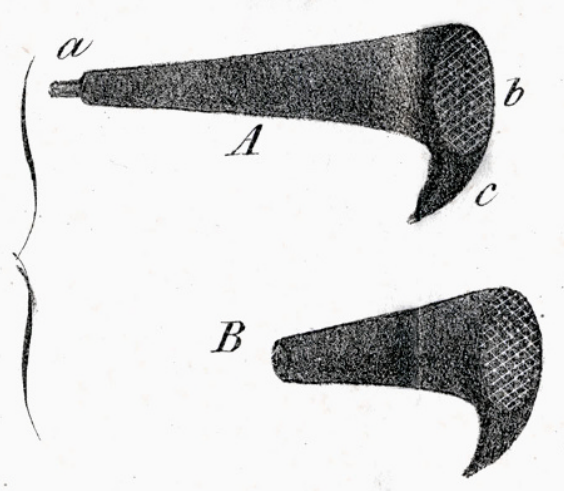

the auditory nerve [64]. As descriptions of the anatomy of the senses and the reproductive organs were lacking in his classic anatomical treatise, Soemmerring supplied some of them with the publication of his Abbildungen des menschlichen Hoerorganes (Illustrations of the Human Auditory Organ) in 1806 [65], which was an international reference for many years. Friedrich Christian Rosenthal (1780-1829) from Greifswald described, in 1823 , the canal in the cochlea, which bears his name [66].

Known for his description of the otic ganglion, the German anatomist Friedrich Arnold (1803-1890) first mentioned in 1829 a "not described nerve" expanding "in the skin of the internal part of the external auditory canal" [67], of which he gave more details 2 years later: "This nerve going to the external ear, which could be termed an ear branch of the lung-stomach nerve (ramus auricularis nervi vagi [auricular branch of pneumogastric nerve]), springs both from the nodule of the voice nerve and from the petrous nodule, then enters the Fallopian canal and goes to the external ear" [68]. Concomitantly, he described a provoked reflex: "I think I should still say only that certain phenomena such as coughing and even vomiting can be adequately explained by touching or stimulating the external auditory canal through the ear branch of the lungstomach nerve [pneumogastric nerve]." This was later named "Arnold's ear cough reflex" [69] or "Arnold's nerve cough."

Emil Huschke (1797-1858) from Jena completed the anatomical works of Soemmerring. He published various 
Hier steht eine Anzeige.

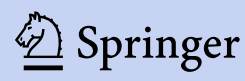



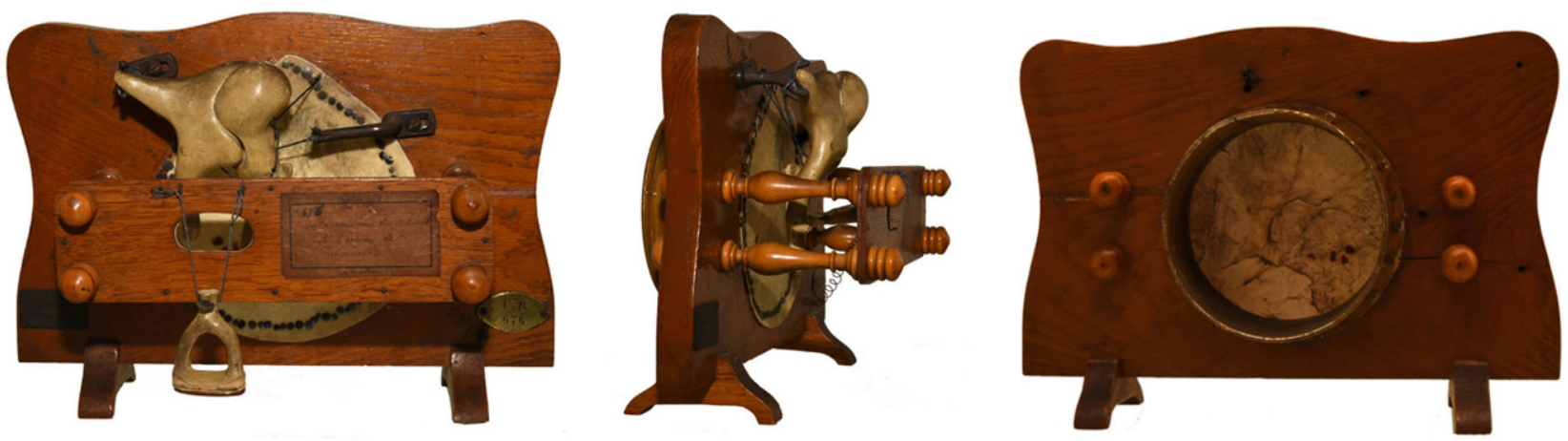

Fig. 4 \ Helmholtz's ossicular chain model. (Private collection. Reprinted with permission $\odot$ A. Mudry, all rights reserved)

works on embryology and paid special attention to the development of the sense organs, particularly the ear and the eye, discovering that both organs originated in a furrow-like fold of the skin. In 1835, he described the incisor-like folds in the cochlear duct of birds, and in particular the auditory teeth [70], later called "Huschke's teeth" [71]. Huschke's name was also associated with a second structure of the ear, the "tympanic foramen" [72]. This was a passage formed by the joining of the two prominences of the tympanic ring near the inner extremity of the tympanic portion of the temporal bone. It normally became ossified and disappeared during early childhood [73].

After the description of the hair cells and the organ of Corti in 1851 [74], Rudolf Albert von Kölliker (1817-1905) of Würzburg conducted numerous anatomical studies of the inner ear [75]. Otto Friedrich Karl Deiters (1834-1863) of Bonn, known for the most comprehensive description of a nerve cell at the time, depicted the supporting cells in the cochlea [76], later named "Deiters' cells" [71]. It guided the reworking of the theories of hearing, notably by Hermann von Helmholtz (1821-1894) from Berlin and his concept that different regions of the basilar membrane act as resonators for tones of different frequency. His main publications were Die Lehre von den Tonempfindungen (On the Sensation of Tone; [77]), which had five editions and was translated into several languages, and Die Mechanik der Gehörknöchelchen und des Trommelfells (The Mechanics of the Ossicles and Tympanic Membrane; [78]), which led him to develop various simulation models (- Fig. 4). He was certainly one of the most remarkable nineteenth-century figures in German physiology. He also moved into the sphere of electrodynamics. He was assisted by Heinrich Rudolf Hertz (1857-1894), whose discovery of "Hertzian waves" made modern wireless transmission possible. In the late 1960s, and in recognition of Hertz, his name was given to the unit of frequency-one cycle per second-and is abbreviated $\mathrm{Hz}$.

Another important discovery was made regarding the physiology of the ear: that the balance organ was in the inner ear, more precisely in the semicircular canals, after the demonstration, in 1824, that in cutting the semicircular canals of birds, balance problems were described [79]. After the recognition that vertigo can stem from a pathology of the ear [80], Friedrich Leopold Goltz (1834-1902) in Halle/S. and Strasbourg went a step further in definitively demonstrating, in 1870 [81], that the balance system is in the semicircular canals. Finally, it was shown that nystagmus was a labyrinthine reflex $[82,83]$. Friedrich Goltz's assistant, Ernst Julius Richard Ewald (1855-1921; [84]), described the two Ewald's laws [85], dealing with the movements of endolymph in the semicircular canals. These were obtained from research on pigeons, using a "pneumatic hammer." Julius Ewald's first law stated that the direction of endolymph flow is in the direction of the slow phase of nystagmus. His second law maintains that ampullopetal endolymph flow in the horizontal semicircular canal causes greater nystagmus response than ampullofugal endolymph flow in the horizontal canal and the reverse was the case for the vertical canals.

In 1860, Gustav Theodor Fechner (1801-1887) in Leipzig [86], introduced the term "psychophysics" and described, with Ernst Heinrich Weber (1795-1878) also in Leipzig, the Weber-Fechner law related to the nonlinear relationship between the physical intensity of a stimulus (such as sound) and the perceived sensation.

Laboratory work facilitated the recognition and the description of many diseases such as cholesteatoma [87] and otosclerosis [88]. The term "cholesteatoma" was coined in 1838 [89] by Johannes Müller (1801-1858) from Berlin because he was aware of the presence of cholesterol and fat in what he believed to be a fatty tumor. Three main theories were then discussed in Germany and abroad to explain the origin of this entity:

- metaplasia of mesenchymal cells

by Rudolf Virchow (1821-1902) in

Berlin [90],

- heterotopia, and

- epithelial migration of the external auditory canal epidermis into the tympanic cavity supported by Friedrich Bezold (1842-1908) of Munich [91].

It then took 40 years of discussion about these three theories to finally confirm that the migration theory was the most probable one. In 1840, Samuel Moritz Pappenheim (1811-1882) from Breslau discovered inflammatory changes in the mucous membrane of the tympanic cav- 


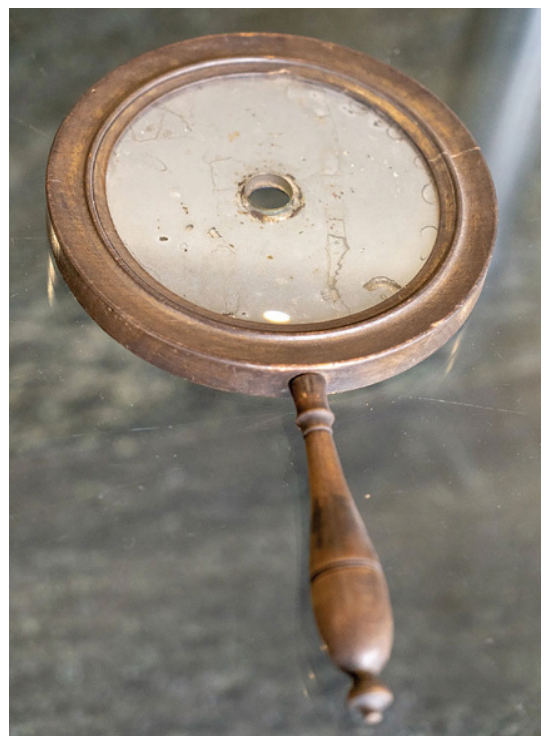

Fig. $5 \Delta$ Hofmann mirror. (Würzburg ORL Clinic Collection)

ity in the case of suppurative otitis resulting from typhus and pneumonia [92]. This was the first step in explaining the origin of otitis media in a modification of the mucous layer of the tympanic cavity.

\section{》) The term "cholesteatoma" was created in 1838}

Clinical examination achieved its definitive landmarks when, in 1841, the Westphalian country physician ("Landarzt") Friedrich Hofmann (1806-1886) from Burgsteinfurt put forward the idea of using a hand-held concave mirror for reflecting and directing sunlight or artificial light onto the ear speculum [93]. A hole was perforated in the center of the mirror to allow direct visualization by the examiner ( 0 Fig. 5). Hofmann also described a funnel-shaped speculum with three mobile branches. Anton Friedrich Freiherr von Tröltsch (1829-1890) [94] from Würzburg made this method popular by claiming its paternity (• Fig. 6; [95]). ${ }^{1}$ He was one

\footnotetext{
1 Tröltsch A. Die Untersuchung des Gehörorgans und Trommelfells. Ihre Bedeutung. Kritik der bisherigen Untersuchungsmethoden und Angabe einer Neuen. Dtsch Klin 1860;12:113-115, 1860;13:121-123, $1860 ; 14: 131-135,1860 ; 15: 143-146$ and 1860;16:151-154.
}

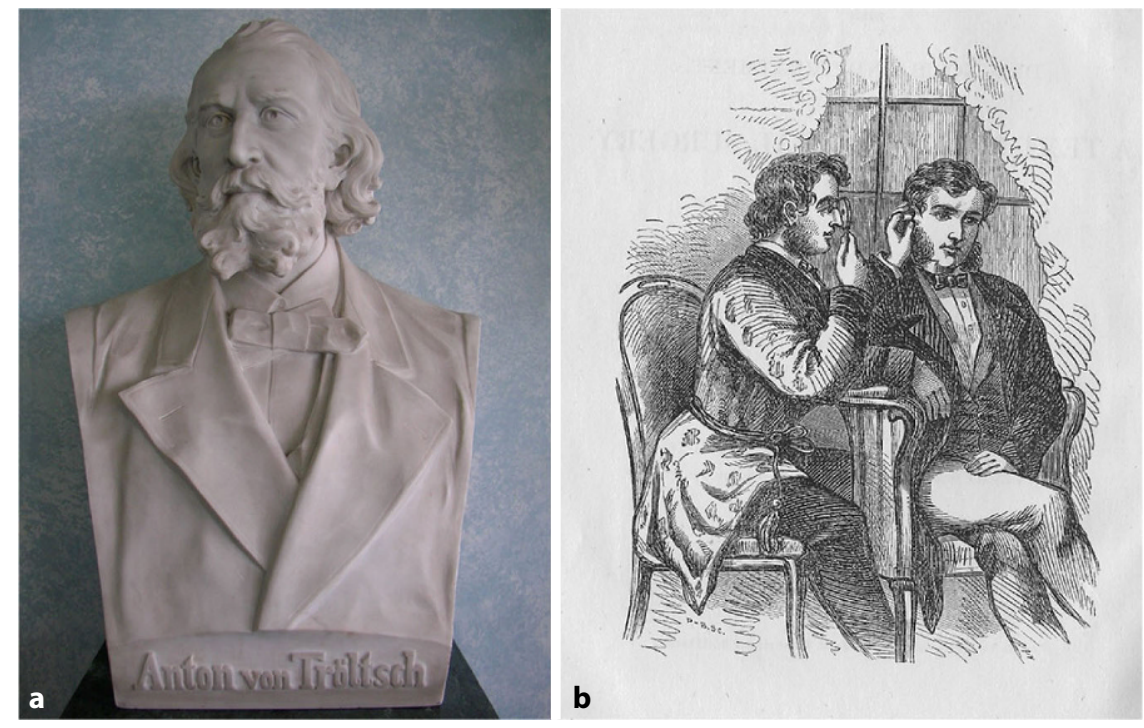

Fig. $6 \Delta$ Anton von Tröltsch and his demonstration of the technique of how to use the adaptation of Hofmann's mirror. a Würzburg ORL Collection; b from Tröltsch's textbook, 1864. (From [279])

of the three founders (together with Adam Politzer [1835-1920] of Vienna and Hermann Schwartze [1837-1910] of Halle/S.) of the Archiv für Ohrenheilkunde (Archives of Otology), the first journal dealing with otology [96]. In 1873 , he was considered as an "outstanding German otologist" [97]. He played an important role in the development of otology not only in Germany, but also abroad. His main textbook, Die Krankheiten des Ohres (Treatise on the Diseases of the Ear; [98]), had seven editions and an international audience with its translation into French, Italian, and English. He also published the first complete text on pediatric otology [99].

Emil Siegle (1833-1900) from Stuttgart invented the pneumatic otoscope [100], an otoscope that allowed the pressure in the outer auditory canal to be modified so that the mobility of the tympanic membrane could be assessed: "When examining patients with ear problems, it is of interest for the physician to obtain information regarding the mobility of the tympanic membrane $[\ldots]$ The instrument used $[\ldots]$ is an approximately one-inch-long by half-inch wide metal cylinder to which an ear speculum is attached at one end by means of a screw mount. The other end is closed airtight, with a piece of glass. On a part of the cylinder a perforated small attachment is located over which an approximately one-foot-long rubber tube is placed [...] the free end of the rubber tubing into his mouth [...] Because of the elastic cover which is placed over the ear speculum the space is airtight and communicates only with the physician's mouth. By a gentle sucking at the rubber hose, it is possible to thin the air in the external ear canal. The ear drum suddenly moves outwards, the ossicles swing around their axes and the light reflex changes and turns broader. Immediately after releasing the suction, everything will return to its old position. All this can be observed through the occluding glass window."

Ernst Florens Friedrich Chladni (1756-1827) of Wittenberg, often referred to as "the father of experimental acoustics," was the first scientist to systematically investigate tuning forks, using his famous powder method to reveal the patterns of vibration on vibrating objects $[107]^{2}$. Ernst Heinrich Weber discovered the phenomenon of the lateralization of sound by the cranium in 1834 [103]; he observed that sound from a tuning fork placed in the middle of the head, and transmitted through the bones, was perceived by both ears. He described his

2 Chladni EF. Entdeckungen über die Theorie des Klanges. Leipzig: Weidmann, 1787 [101]. Chladni EF. Die Akustik. Leipzig: Breitkopf \& Härtel, 1802 [102]. 

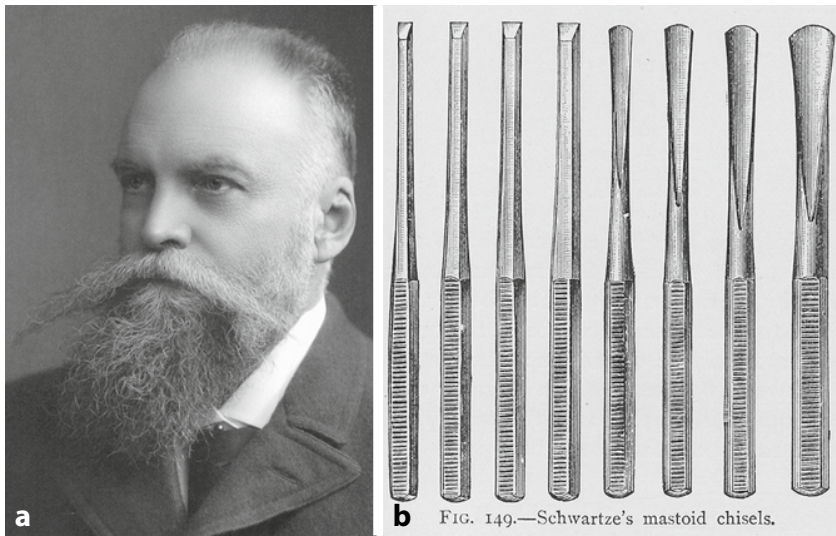

Fig. $7<$ a Hermann Schwartze. (ORL Clinic Halle, Reprinted with permission $\odot$ University Archive, Martin-Luther University HalleWittenberg, UAHW, Rep. 40, VI, Nr. 1 Bild 39, all rights reserved). b mastoid chisels. (From Dench's textbook, $1896,[280])$ test as follows: "If we firmly block one ear with a hand and voice a sound, we perceive very clearly that it is heard much better and much louder by the blocked ear than by the unblocked one [...] If we touch our teeth with the point of a tuning fork (oscillating musical fork) producing a not too high-pitched sound, and we block our mouth as much as possible with the lips and tongue, and at the same time close our ears either by pressing our hands against them, or by putting a finger in the auditory canal, we are struck more forcibly be the sound of the tuning fork than with our ears open. If one ear is closed and the other open, we hear a louder sound in the closed ear than in the open one. We observe the same thing if we close the right ear and apply the point of the tuning fork to the skin of the left temple; even if the tuning fork is nearer the left ear and the auditory canal and is much farther away from the right ear, it has a much stronger effect in that ear than in the left one, and vice versa."

The tuning fork saw another use in 1855, when Heinrich Adolf Rinne (1819-1868) described another test in 1855 [104]: "A simple test shows us to what extent the normal conduction of sound by air and the tympanic membrane etc. prevails over conduction through the cranial bones, even for sounds which are produced by the oscillation of a solid body and are transmitted directly onto the skeleton. I apply to the upper incisors a tuning fork producing a sound and leave it in place until the sound which was at first very clear is no longer audible to me. I then move the tuning fork in front of the outer ear and hear the sound again very strongly. Only after a certain time does the sound stop here also. All the people with healthy ears on whom I have done this test have produced the same result [...] If the patient hears the sound transmitted through the cranial bones for as long as or longer than the sound transmitted in the normal way, we conclude that part of the conduction system, including the membrane of the oval window, is diseased; this can also be caused by a motor affection of a nerve." This test was introduced into practice by Johann Constantin August Lucae (1835-1911) from Berlin [105] and supported by Friedrich Bezold [106, 107] in the 1880s. Dagobert Schwabach (1846-1920) from Berlin completed these tuning fork tests with his own test [108].

In 1802, Christian Heinrich Wolke (1741-1825) developed the first "acuity meter" designed specifically to measure hearing [109]. Various other models and methods were then proposed, notably the use of a pocket watch [110]. The first audiometer was developed by the German otologist Arthur Hartmann (1849-1931) in 1878 [111]. His "Akumeter" combined the electrical tuning fork and the telephone receiver [112]. At the same time, others were produced in the United Kingdom and elsewhere. Since it was not commercially produced, it was not available and thus disappeared from history. In 1881, Arthur Hartmann wrote the textbook Die Krankheiten des Ohres und deren Behandlung(The Diseases of the Ear and Their Treatment; [113]), which had eight editions and translations into English, French, and Italian.

In the second part of the nineteenth century, great progress was made in the field of ear therapy. In 1873 Hermann Schwartze [114] and his assistant Adolf Eysell (1846-1934) [115] of Halle proposed a new technique to open the mastoid by using a chisel and gouge, often called "modern mastoid operation" or Schwartze operation. Hermann Schwartze's chisel was a short-bladed hand tool with a straight, beveled cutting edge and a plain handle that was struck with a mallet (• Fig. 7). The gouge derived from the same instrument but had a concave, beveled cutting edge. Hermann Schwartze did not depict his instruments in his publications, but illustrations were published by colleagues. Hermann Schwartze described the advantages of the chisel and gouge over the trepan and other perforators. This new instrumentation enabled the creation of a larger, safer, funnel-shaped opening of the mastoid region down to the antrum for drainage of mastoid abscesses. It also expanded the indications for mastoid surgery, notably to include cases of chronic otitis.

Mastoidectomy rapidly became a routine operation [116]. Based on his extensive surgical practice requiring in-hospital treatment, he was able to move into the first hospital in Germany solely built for the specialty in 1884 with 25 beds for otology patients only (and a similar number for ophthalmology). Different types of mastoidectomy (cortical, radical, and modified radical) were developed mainly in Germany. During the winter of 1888-1889, two general surgeons from Berlin, Ernst Küster (1837-1930; [117]) and Ernst von Bergmann (1836-1907; [118]), read papers before the German Surgical Society in which the former recommended the removal of the posterior meatal wall and the latter the outer attic wall. Ernst Küster wrote: “The rational treatment must be based on the surgical principle that a diseased bony cavity should be opened up extensively, all diseased tissue removed, and the source of suppuration brought clearly to the light. The pus must nowhere be hindered in its outflow." These principles were also 
further advanced notably in Germany by Ludwig Stacke (1859-1918) of Erfurt, who sought to combine the tympanum, attic, and antrum into one cavity, which facilitated inspection and dressing. Ludwig Stacke worked backward from the attic to the antrum [119], while some others worked forward from the antrum to the attic.

In 1889 Otto Körner (1858-1935) from Rostock suggested a modification of the radical operation that consisted in removing the upper posterior wall of the auditory canal and the outer wall of the antrum, leaving some of the outer attic wall in order to preserve the malleus and incus. Hermann Schwartze in 1893 also extended his own simple mastoidectomy to include removal of the posterior and superior meatal walls and middle ear contents. One of the problems with the earlier cases of radical mastoidectomy was that after healing, the cavity became inaccessible from the ear canal. To overcome this, meatoplasty was devised by Ludwig Stacke, Hermann Schwartze, and Rudolf Panse (1863-1942) of Dresden, among others. The enlarged meatus gave good access to the cavity and enabled closure of the postaural wound by primary suture. Before meatoplasty it was quite common for a deliberate postaural fistula to be created to facilitate dressing of the mastoid cavity.

There followed a period of approximately 7 years during which time many ears were automatically subjected to the radical operation and patients suffered from often unnecessary hearing loss. The same men who first advocated the radical procedure were themselves the first to attempt to save the ossicles and hence the hearing. They thus initiated the phase of conservatism aimed at the preservation of the middle ear function in those cases with only atticoantral disease and otherwise healthy middle ears.

The gradual realization that a fixed stapes alone could cause hearing loss encouraged certain otologists to propose freeing it in an attempt to improve hearing. This was done by Johannes Kessel (1839-1907) in Jena in 1876 [120]. He removed the columella from pigeons and the stapes from dogs, then stimulated their hearing, and observed that with the healing of the oval window, in which the stapes is normally situated, their hearing improved. He concluded that removal of the tympanic membrane and of the malleus and incus bones, combined with freeing of the stapes, could be a treatment for hearing loss. Two years later he examined a patient who had gone deaf after falling from a cart. The patient died and the autopsy showed a fracture across the horizontal semi-circular canal. Kessel concluded that the canal was part of the hearing function and that it had to be intact to allow hearing to be good. He deduced that, if the stapes became fixed, hearing could probably be improved by opening a semicircular canal. He thus advocated fracturing the horizontal semi-circular canal and excising the fixed stapes. The oval window was then covered by a graft [121]. The effects on hearing were inconsistent. Johannes Kessel was also a precursor of radical mastoid surgery through an endaural approach [122, 123].

Hier steht eine Anzeige. 


\section{Leitthema}

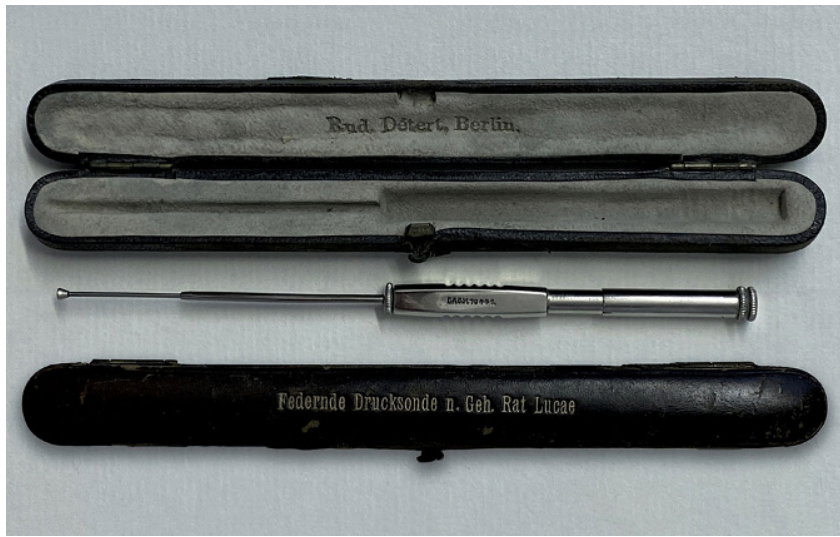

Fig. $8<$ August Lucae spring probe. (Reprinted with permission $\odot$ R. Mlynski, all rights reserved)

Also aiming to solve a fixation of the stapes, August Lucae in 1884 [124] introduced a new "method to mechanically treat chronic troubles of the mobility of the hearing organ transmission apparatus." It consisted in the use of a springy pressure probe to directly mobilize the handle of the malleus (• Fig. 8; [125]). Another idea was proposed by Karl Adolf Passow (1859-1926) [126] from Berlin, who, in 1897 , reported to have made a window in the promontory and covered it with the tympanic membrane [127]. His patient noted a slight improvement in hearing. It precluded the fenestration operation.

The concept of a surgical repair of the tympanic membrane with a skin graft is usually credited to Emil Berthold (1836-1922) from Königsberg, in 1878 [128]: "The first step is to free the margin around the perforation and the lipshaped epithelization of the margins of the perforation from the epithelium in order to change (render) these parts into a wound which enables the healing of a freshly excised piece of skin. For that purpose, I glue a court-plaster over the site of perforation so that the eardrum is covered by it still several millimeters distant from the perforation. After three days I remove this plaster. I harvest the piece of skin from the forearm. I introduce this piece of skin into the external ear canal and press it with its wounded surface over the margin of the perforation" $[129,130]$. He termed his new technique "myringoplasty."

In 1902, the term "cerebellopontineangle tumor" was introduced by Richard Henneberg (1868-1962) of Berlin [131].
During these early years of the century, although the surgery of cerebral tumors was in considerable disarray, largely due to the publication of Ernst von Bergmann's discouraging views on the subject, the first operations on suspected acoustic tumors were undertaken [132]. Fedor Krause (1857-1937) of Düsseldorf in 1903 reported an $83.8 \%$ operative mortality using the unilateral suboccipital approach [133]. Only 1 year later, Rudolf Panse in 1904 proposed that an approach through the labyrinth may allow for removal of an acoustic neuroma as large as a hen's egg [134]. He defined the anatomical limits of this exposure as the lateral sinus, the jugular bulb, the carotid artery, and the temporal lobe. The facial nerve, he thought, should be sacrificed, but he did concede that with certain tumors it might be possible to re-route the nerve by mobilizing it from the geniculate ganglion to the stylomastoid foramen.

\section{》) Otology was a fruitful specialty in Germany throughout the 19th century}

During the first part of the nineteenth century, otology lectures were given-except for Gustav Lincke in Leipzig and Wilhelm Kramer in Berlin essentially by surgeons and ophthalmologists such as Karl Gustav Himly (1772-1837) in the 1830s, and Ernst Ludwig Schillbach (1825-1898) in the 1850 s, both from Jena [135], or Johann Adolf Winter (1816-1901) in Leipzig in the 1840's. In 1852, Adolf Winter opened a private polyclinic for ear pa- tients [13]. The first known academic lecturer titles (Privatdozenten, "PDs") in otology were Edmund Traugott Adolf Dann (1805-1851) in 1832 [136] and Martell Frank (1810-1886) in 1849 [17], both in Munich. From 1859, many other otologists received their title as Privatdozent. In 1866, Salomon Moos (1831-1895) of Heidelberg was probably the first to become "extraordinary professor" in otology in Germany [137]. In 1878 [138, 139], in 14 of the 20 German universities, otology lectures were given by PDs or extraordinary professors. At the same time, 12 universities had a clinic or a subsidized polyclinic. In 1892, the German Otological Society was founded [140], while the first otological society was created in New York as early as in 1868 [141]. In 1902, all universities proposed lectures in otology [12]. In 1878, Anton von Tröltsch contacted the government to propose otology as a topic to be tested during the final examination for becoming a physician [138].

Throughout the 19th century, otology was a fruitful specialty in Germany. All its aspects were studied and developed, at the same time as numerous German innovations were implemented in the world of otology.

\section{Laryngology (pharyngo- laryngology and endoscopy)}

The beginning of laryngology as a subspecialty is usually associated with the invention of the laryngeal mirror in 1855 [142], but most effectively it was in the 1880 s, a time when it was possible to operate in the larynx with local anesthesia [143]. Laryngology was much less developed than otology, and some of the foundations of the subspecialty were established in the first part of the nineteenth century.

In anatomy, Ludwig Julius Caspar Mende (1779-1832) of Greifswald discussed in detail the motility of the vocal cords in 1816 [144]. The mechanism of the falsetto voice was a source of concern and investigation. Carl Lehfeldt (1811-1891) of Berlin in 1835 [145] offered an explanation that the falsetto tones arose from the larynx alone and that they were produced by vibration only 
of the edges of the vocal folds. The gross anatomy of the faucial tonsils had been studied and described from the earliest times. Albert von Kölliker, in 1852 [146], was the first to demonstrate the folds and depressions of the mucosa, the follicles in their walls and the epithelium. The finer structures of the lymphatic network, however, escaped the relatively feeble power of his microscope. Kölliker regarded them as part of the lymphatic system and related to the Malpighian corpuscles of the spleen. When Albert von Kölliker described the faucial tonsils, he mentioned the existence of similar tissue in the nasopharynx. Jacob Henle (1809-1885) of Heidelberg insisted that the "pharyngeal bursa" was a normal structure [147]. He already confirmed, in 1838 [148], the existence of different forms of epithelial covering. He identified pavement, cylindrical, and ciliated forms and found the latter types on the anterior wall of the larynx and on the posterior wall only immediately above the superior vocal ligaments. As early as in 1805, Johann Christian Rosenmüller (1771-1820; [149]) of Leipzig described the pharyngeal recess behind the ostium of the Eustachian tube, which bore his name [150]. In 1816, he also published a dissertation on the defect of the olfactory nerve [151].

In 1884, Heinrich Wilhelm Gottfried von Waldeyer-Hartz (1836-1921) of Berlin described the arrangement of lymphoid tissue around the junction of food and air passages [152] under the terms "tonsillar ring" or "lymphatic throat ring," later eponymously known as "Waldeyer's ring." In 1868, Hubert von Luschka (1820-1875; [153]) of Würzburg provided a full description of the median and lateral recesses of the pharyngeal tonsil that belonged to Waldeyer's ring. In the roof or vault of the pharynx, follicular glands are arranged [154], called "tonsil of Luschka" [155]. In 1885 Gustav Ludwig Tornwaldt (1843-1910) of Danzig described [156] the diverticulum of the pharyngeal tonsil, which was eponymously named “Tornwaldt's pharyngeal bursa" [157]. It was first mentioned in some animals in 1840 [158].
The growing importance of laryngeal pathology was emphasized in 1829 by the publication of a book, Die Pathologie und Therapie der Kehlkopfskrankheiten (Pathology and Therapy of Larynx Diseases), which was devoted to laryngeal diseases [159], by Johann Friedrich Hermann Albers (1805-1867), an anatomist in Bonn. It contains separate sections on simple catarrh and chronic hypertrophic catarrh of the mucous membrane, of syphilitic and tubercular ulcerations, of disease of the cartilages, as well as growths and paralysis of the larynx. In 1836, a characteristic condition of the floor of the mouth, which usually arises from infection of the lower molar teeth and can give rise to respiratory obstruction, was described by Wilhelm Frederick Ludwig (1790-1865; [160]) and is still known as "Ludwig's angina" (angina Ludovici). Wilhelm Frederick Ludwig died after developing an inflammation of the neck, raising the question that he might have died of "his own" condition [161].

Clinical examination of the upper aerodigestive tract found its "letters of nobility" in the second part of the nineteenth century. Philip Bozzini (1773-1809), working in Frankfurt/M. in 1806, described a double cannula with two mirrors placed at $45^{\circ}$ at the end $[162,163]$. The light was transmitted through one compartment and reflected from the mirror onto the parts to be examined. The image was received on the other mirror and reflected back to the eye through the second compartment. A wax candle provided the illumination, and the instrument that Philip Bozzini called the "Lichtleiter" was used to inspect a variety of canals including the larynx and the ear, although it is doubtful that he ever saw any part of the latter with this instrument. It launched a new era in the possibility to examine the upper aerodigestive tract, but it took more than a half century to be efficiently developed.

Credit for the first direct esophagoscopy is given to Adolf Kussmaul(1822-1902) of Freiburg, who in 1868, using a Desormeaux urethroscope elongated to $24 \mathrm{~cm}$, managed to diagnose cancer of the thoracic esophagus [164-167]. $\mathrm{He}$ was unable to reach the cardia and so lengthened the instrument to $47 \mathrm{~cm}$ but despite using the services of a professional sword swallower there is no record that he actually entered the stomach. One of his pupils succeeded in safely introducing a rigid tube $13 \mathrm{~mm}$ in diameter into the esophagus of a healthy person. In the same year, Louis Waldenburg (1837-1881) of Berlin designed an esophagoscope, first consisting of a short gum elastic tube $8 \mathrm{~cm}$ in length [168, 169]. It was connected to a two-pronged fork, which enabled it to be secure while a laryngeal mirror was inserted into the mouth in order to see down the tube. He later designed a telescopic metal tube and attached a mirror to it.

\section{》) The interior of the larynx was observed by direct examination for the first time in 1895}

On April 23, 1895, Alfred Kirstein (1863-1922; [170]) of Berlin observed for the first time the interior of the larynx by direct examination [171, 172]. $\mathrm{He}$ used a flat spatula and Caspar's electroscope, and with the patient's head extended, he depressed the tongue and epiglottis, calling this examination "Autoscopie" (• Fig. 9). After some experimentation, he concluded that indirect laryngoscopy was the best technique for viewing the anterior part of the larynx but that his direct method gave a better view of the posterior part of the larynx. He later abandoned the Caspar electroscope as it occluded the view and interfered with instrumentation. $\mathrm{He}$ substituted his own design of head lamp. Impressed by the work of Alfred Kirstein, Gustav Killian (1860-1921) of Freiburg [23], in 1896, began devoting his entire time to endoscopy. He adapted the esophagoscope, enabling him to perform a bronchoscopy in 1897 [173] and coined the term "bronchoscopy" [174]. Using tubes of an exterior diameter of between 9 and $10 \mathrm{~mm}$, he was able to examine the main branches of the bronchi and their second and third divisions. Gustav Killian designed a short split laryngeal spatula to facilitate easier introduction of the tubes. Initially the procedure 

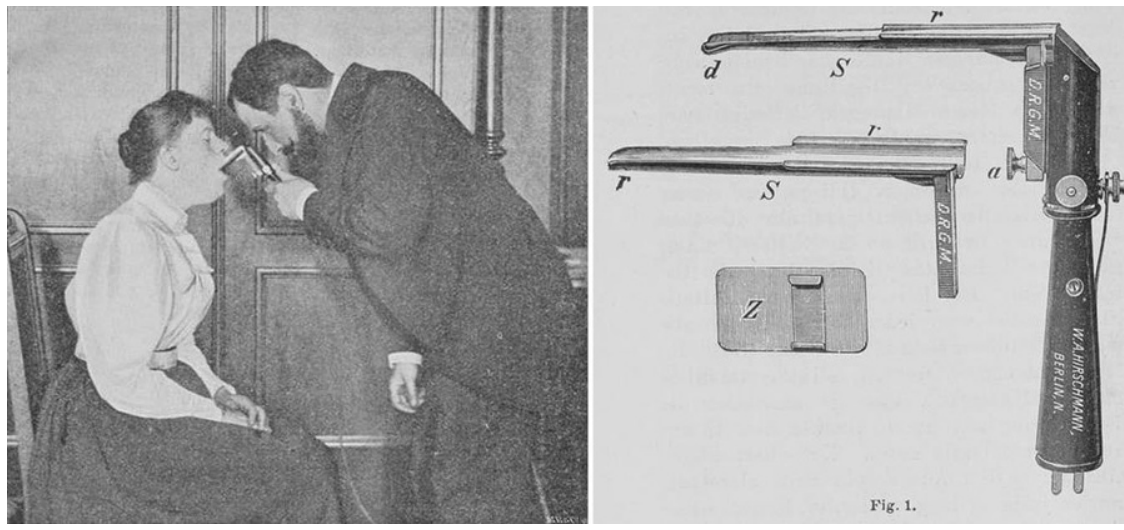

Fig. $9 \Delta$ Kirstein (left) demonstrating the use of his autoscope (right) (From Kirstein's 1895 publication, [171])

was performed with the patient seated on his specially designed chair. Later in 1911, he introduced the dorsal position for the patient and suspension laryngoscopy, which enabled him to free both his hands. Gustav Killian was the first to remove a foreign body (a bone) from the bronchus and in 1900 he succeeded, using a galvanocautery snare, in cutting in half a vulcanite dental plate that had become impacted deep in a patient's esophagus. After the remarkable progress of endoscopy during the last 20 years of the nineteenth century, endoscopy made its marks in the first two decades of the twentieth century [175, 176]. Wilhelm Brünings (1876-1958) of Jena, who had been Gustav Killian's chief assistant, introduced the idea of double extension tubes to bronchoscopes and esophagoscopes in 1908. His book Die direkte Laryngoskopie, Bronchoskopie und Oesophagoskopie (Direct Laryngoscopy, Bronchoscopy, and Oesophagoscopy) published in 1910 [177] was translated into English. Wilhelm Brünings was not only a designer of endoscopic instruments but also a pioneer in the teaching of this new specialty.

\section{》) Gustav Killian coined the term "bronchoscopy" in 1897}

The study of vocal cord movement was further aided by the first presentation in 1878 [178] of a stroboscope by Max Joseph Oertel (1835-1897) from Munich, which saw its final form in 1895 [179-181]. It allows one to analyze the vibration behavior of the vocal fold mucosa, making surgery of the vocal fold mucosa manageable.

Therapy saw great progress in the second part of the nineteenth century. Tracheostomy was well established, as was tonsillectomy as a routine operation notably after the introduction of a kind of guillotine, the "tonsillotome" [182], by modifying an instrument to section the uvula in the 1820s. This instrument saw various modifications up until the beginning of the twentieth century. It was gradually replaced in the twentieth century by the "dissection technique," with the patient placed on their back with a sandbag under the shoulders and with the head well extended. Nevertheless, due to an inadequate technique, tonsillectomy was regularly considered as "tonsillar massacre" [183]. Recognition of the importance of the adenoids, described in 1868 [184, 185], in the development of middle ear infections opened a new era in the comprehension of otitis. Removal of the adenoids quickly became a routine operation, first with a type of ring-knife and then with the curette. In 1886 Jacob Gottstein (1832-1895) of Breslau introduced the adenoid curette [186], which has since been modified by many surgeons, notably Hugo Beckmann (1861-1907) in Berlin (• Fig. 10; [187]). The operation was initially performed without anesthetic but by the early 1890 s general anesthesia was introduced.

Albrecht Theodore Middeldorpf (1824-1868) of Breslau described in Die Galvanocaustik (The Galvanocaustic) published in 1854 [188] the successful removal of a polyp, which was said to have arisen from the upper part of the larynx, using an incandescent platinum wire loop. He pulled the tongue forward with a sharp hook and guided the wire loop around the tumor with his fingers. In 1862 Victor von Bruns (1812-1883) in Tübingen claimed that [189] he had successfully removed a growth from his brother's throat using forceps. In 1868, he published a series of 23 observations of laryngeal polyps [190]. Nevertheless, the extent of treatment that the laryngologist of the last quarter of the nineteenth century could offer was limited to the opening of abscesses, the removal of tonsils, and the endolaryngeal removal of polyps and other small tumors of the larynx. Caustic, astringent, or sedative solutions were applied to the larynx with a camel hair brush or syringed or sprayed into it; alternatively, astringent or sedative powders were blown in by an insufflator. Functional or hysterical loss of voice was treated by applying galvanic current to the vocal folds. The diagnosis between chronic laryngitis, syphilis, tuberculosis of the larynx, and malignant disease was always difficult and sometimes impossible, even for the experienced laryngologist. The introduction of cocaine as local anesthesia for the larynx led to a new therapeutic era.

\section{》) The first laryngectomy was performed by Theodor Billroth in 1873}

In 1854, Bernhard Rudolf Konrad von Langenbeck (1810-1887) of Berlin proposed to a patient the extirpation of the larynx for a malignant disease, but the patient declined [191]. Surgeons were now prepared to extirpate diseased organs such as the larynx, which was reported to be successfully performed for the first time by Theodor Billroth (1829-1894) from Bergen a. Rügen in 1873 in Vienna [192], creating a definitive opening of the trachea in the neck. The early laryngectomies were fraught with complications, the main one being aspiration. Some surgeons attempted to avoid complications by performing 
a preliminary tracheotomy several weeks before the excision of the larynx. In 1875, Bernard von Langenbeck realized that cervical lymph node metastases, if present, had to be removed with the primary tumor if the patient was to be given a chance of survival $[193,194]$.

In 1880, Max Schüller (1843-1907) in Greifswald published one of the first German books on tracheotomy, laryngotomy, and removal of the larynx [191]. One year later, Themistokles Gluck (1853-1942) of Berlin [195] suggested severing the trachea from the larynx and suturing it to the skin [196]. He favored removing the larynx from above and closed the pharyngeal defect before finally detaching the larynx from the trachea. This improvement was made in conjunction with his colleague Johannes Soerensen (1862-1939; [197]). Bernhard von Langenbeck, Themistokles Gluck, and Johannes Soerensen regularly examined the vessels of the neck and removed lymph node metastases together with the sternomastoid muscle, the internal jugular vein and, on occasion, the carotid artery. Neck dissection was thus included in surgical treatment.

In the second part of the nineteenth century, vocal rehabilitation methods included the development of esophageal speech and the use of mechanical vibrators. The first successful reports of pharyngeal speech in Germany came from Hans Schmid (1853-1896) of Stettin, in 1888 [198, 199], and Jacob Gottstein in 1900 [200]. Only Julius Wolff (1836-1902) of Berlin in 1893 was able to create different sounds in his artificial larynx as a result of a rubber tongue that could be elongated or shortened with the turn of a screw [201]. After the remarkable development of esophageal and bronchial endoscopy during the last 20 years of the nineteenth century, endoscopy made its mark in the first two decades of the twentieth century, also becoming therapeutic. It was included in the domain of most OHNS specialists.

In the 1860 s, the first lectures in laryngology were essentially concentrated on the correct use of the mirror to examine the larynx. These lectures were usually called "laryngoscopy." At the same time, the first academic lecturer PDs in laryngology were received, e.g., by Georg Richard Lewin (1820-1894) in Berlin in 1862 , becoming extraordinary professor 6 years later [16]. He was followed by many others in the different German universities. The lectures progressively changed to become true laryngology lectures in the 1880s, often associated with lectures on rhinology. In 1887, one of the first independent polyclinics for laryngology and rhinology opened in Berlin. The Berlin Laryngological Society was founded 2 years later under Bernhard Fraenkel (1836-1911), followed by the German Laryngological Society in 1894, while the first laryngological society was created in New York as early as in 1873 [202]. In 1908, only six German universities had a laryngology clinic [203].

Contrary to otology, laryngology saw its main development in Germany in the second part of the nineteenth century. Different German protagonists played an important international role, notably in the area of examination and treatment.

\section{Rhinology}

Rhinology is often considered as the poor relative in the history of OHNS. It was usually associated with laryngology. Nevertheless, it tried to find its own way at the end of the nineteenth century.

In anatomy, an early reference to the erectile tissue [204] in the nose was made by Otto Ludwig Bernard Kohlrausch (1811-1854) of Hannover, who in 1853 [205] spoke of cavernous tissue of the posterior border of the inferior turbinate.

There was important progress in clinical examination with the possibility to access the posterior part of the nose. Friedrich Eduard Rudolf Voltolini (1819-1889) of Breslau [206] introduced posterior rhinoscopy in 1859 and invented an oxyhydrogen incandescent light to aid examination of the ear and larynx. He actively pursued posterior rhinoscopy as an aid to the passage of the eustachian catheter. In 1861, he published the first edition of his textbook Die Rhinoskopie und Pharyngoskopie (Rhinoscopy and Pharyngoscopy; [207, 208]).
Hier steht eine Anzeige.

Springer 


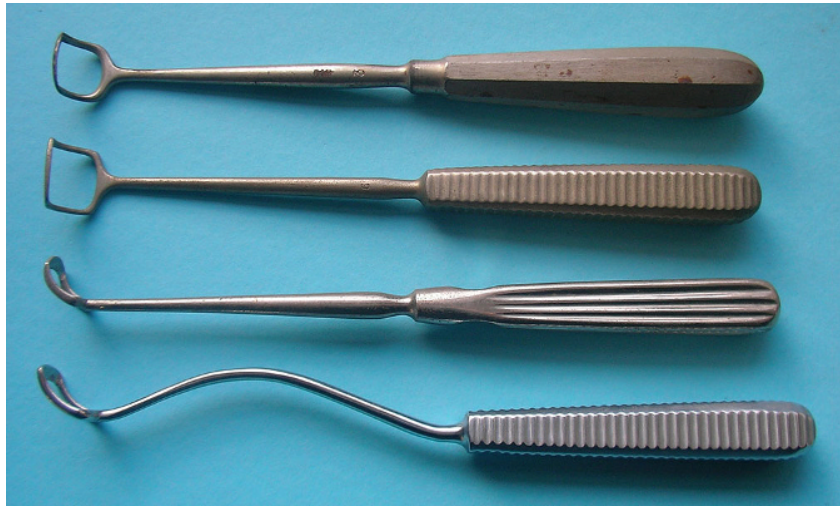

Fig. $10<$ Beckmann's curettes. (Personal collection, Dr. Lübbers. Reprinted with permission $\odot$ W. Lübbers, Hannover, all rights reserved)
It was only 6 years later, when radiology was discovered, that Max Scheier (1864-1921) of Berlin was quick to see its value in the diagnosis of sinus disease. His pictures of 1896 were neither perfect nor convincing, but they showed that-given further development-the technique was promising. He published them in 1897 [209, 210]. The name of W. Alfred Hirschmann of Berlin is associated with the introduction of sinoscopy since 1901 [211, 212] in Germany. He managed to reduce a Nitze's cystoscope to a diameter of $4.0 \mathrm{~mm}$ in order to study the middle meatus and sinus ostia (- Fig. 11). He originally entered the antrum through a molar tooth socket but he also trephined the canine fossa. Diagnostic puncture of the maxillary antrum attracted some authors in close succession. Hermann Krause (1848-1921) of Berlin in 1887 [213] modified Mikulicz's trocar by adding a cannula to permit antral lavage.

In the mid-nineteenth century there was a great difference of opinion concerning the pathology of nasal polyps. Maximilian Joseph von Chelius (1794-1876) in Munich still supported the concept of the Middle Ages, that polyps result from a local infiltration of mucous membrane with serum [214]. In 1854 some considered that nasal polyps were adenomatous swellings and Rudolf Virchow in 1863 called them "myxomata." It was then suggested that nasal polyps arose from a chronic infection of the ethmoid air cells.

The plexus of veins situated on the anterior part of the cartilaginous septum was identified as a source of epistaxis by Carl Michel (1843-1930) of Cologne in 1874 [215], and Wilhelm Kiesselbach (1839-1902) of Erlangen in 1880 [216] and 1884 [217]. This area was later named "Kiesselbach's plexus." To treat epistaxis, the German Johann Peter Frank (1745-1821) appears to have been the inventor, as early as in 1807 , for he was the first to devise a special instrument (balloon tamponade if it can be called so) to bring pressure to bear directly on the walls of the nasal fossae. $\mathrm{He}$ introduced into the nose a piece of dried hog's intestine, tied at the distal end, and then injected water into the open-end projecting from the nostril, tying up the gut as he withdrew the syringe [218, 219]. Over time, the pig intestine became a rubber fingerling or a condom, which had just come on the market at the end of the nineteenth century.

In 1886 Karl Konstantin Heinrich Ziem (1850-1917) of Danzig stressed [220] that the origin of sinus disease was to be found in the nose. The term "sinusitis" appeared in the rhinology literature at the turn of the 1890s. It became rapidly used worldwide to describe an inflammation of the paranasal sinus. In 1882, Wilhelm Hack (1851-1887) of Freiburg im Breisgau raised the awareness of laryngologists to the association of upper airway disease with asthma [221].

\section{》) Surgery made big strides with the refinement of rhinoplasty and septoplasty}

Surgery took a big step forward with the development and refinement of rhino- plasty and septoplasty. Carl Ferdinand von Graefe (1787-1840) of Berlin introduced the term "rhinoplasty" in his book published in 1818 [222] and in reviving the Italian method by combining its best features with the Indian method, thus creating a European technique and becoming the founder of modern plastic surgery. He was succeeded in Berlin by Johann Friedrich Dieffenbach (1792-1847), who emphasized constructive rather than ablative nasal surgery: “The nose is man's most paradoxical organ. It has its root above, its back in front, its wings below and one likes best of all to poke it into places where it does not belong." Friedrich Dieffenbach remarked that "only very young and very healthy people with great courage can endure it and the surgeon must have great experience" [223, 224]. He also proposed using gold removable supports to keep the nostrils open. In 1822, Heinrich Christian Bünger (1782-1824) of Marburg used the Indian technique with a flap from the leg [225]. Friedrich Dieffenbach was one of the first to use ether anesthesia. He introduced the "endonasal" approach to rhinoplasty and his Die Operative Chirurgie (Operative Surgery) published in 1845 [226] contains over 100 pages on flap reconstruction of noses, including $\mathrm{V}$-Y advancements and Z-plasties of the nasal base. He also tried to include a gold plate to sustain a saddle nose. By the end of the nineteenth century, the principles and practice of rhinoplasty were well established [227]. In 1898 Jacques Lewin Joseph (1865-1934) of Berlin introduced modern rhinoplasty [228] with the publication of his paper, "Ueber die operative Verkleinerung einer Nase" ("Operative reduction of the size of the nose"; [229]). He was an orthopedic surgeon, and the patient described was a male suffering from depression, on whom Jacques Joseph performed a large reduction rhinoplasty. It was done through an external dorsal $\mathrm{V}$-shaped incision, with excision of redundant dorsal skin. Jacques Joseph was a gifted illustrator who analyzed and classified rhinoplasty surgery and invented surgical instruments. In 1904, he began performing rhinoplasty through intranasal rather than external 


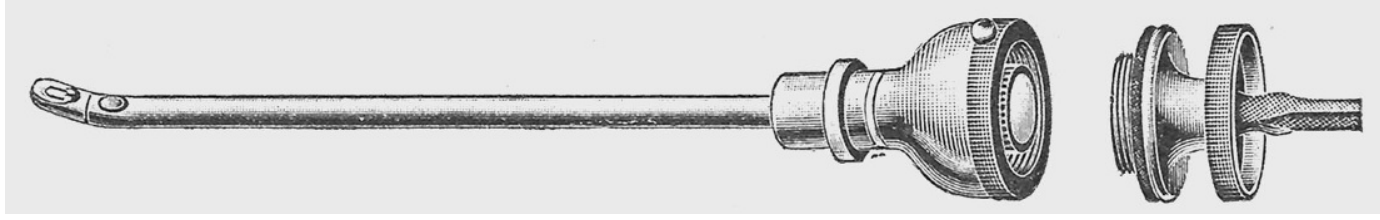

Fig. $11<$ Hirschmann nasal endoscope, 1905. (From Reiniger-Gebbert \& Schall. Elektro-Med. Apparate, [281])

incisions, thus establishing a series of techniques that have been used by generations of rhinoplasty surgeons. His book Nasenplastik und sonstige Gesichtsplastik (Rhinoplasty and Facial Plastic Surgery), published in two parts between 1928 and 1931 [230] and later translated into English, became a classic text. He developed numerous instruments to perform his surgery [231]. The refinements and introduction of facial plastic surgery were facilitated by the great contribution of Jacques Joseph. The term "plastic surgery" was introduced in 1838 by Eduard Zeis (1807-1868) in Marburg in his Handbuch der Plastischen Chirurgie (Textbook of Plastic Surgery; [232]). In 1863, Eduard Zeis published the first exhaustive repertory of references in the history of rhinoplasty [233].

\section{》) Ludwig Grünwald described an intranasal approach to the ethmoid sinuses}

In 1834 Conrad Johann Martin von Langenbeck (1775-1851) of Göttingen (the uncle of Bernhard von Langenbeck) described a method of shaving down acute spurs and angulations of the nasal septum [234] and exostoses on the septal wall [235]. Others recommended complete removal of the deviation using punch forceps. Most of these procedures inevitably exchanged a septal deflection for a septal perforation. The idea of removing the deflected cartilage and bone submucosally came simultaneously to a number of independent workers in the midnineteenth century. Wenzel von Linhart (1821-1877) of Würzburg protected the nasal mucosa of both sides in practicing the resection of the septum in 1862 [236]. Since 1879, Arthur Hartmann used a raspatorium to separate the nasal mucosa from the septum [237]. The year 1882, however, definitively marked the beginning of the codification of submucous resection of the septal wall with specially designed instruments [238]. Very similar procedures were recommended by Robert Krieg (1848-1933) of Stuttgart in $1886[239,240]$ and Georg Boenninghaus in 1895 [241]. The latter was the first to publish long-term results. Gustav Killian's submucous resection operation [242] gained popularity throughout the world, but it became apparent that problems could occur with the anterior part of the septum, mostly in the form of supratip depression and columellar retraction. The concept of a "septoplasty" operation gradually developed, where the cartilaginous septum, still attached to its mucoperichondrium, was mobilized and repositioned in the midline [243-245].

The significance and surgical drainage of the maxillary antrum were fully explored in the seventeenth and eighteenth centuries, but were ignored and neglected most of the time. On the whole, little new knowledge was added until the beginning of the development of modern rhinology in the early 1880s. Max Schaeffer (1846-1900) from Bremen performed endonasal ethmoid surgery and transnasal sphenoid surgery in 1885 , easily piercing the sphenoid anterior wall with a sharp spoon probe [246]. The textbooks of the day contained few pages on sinus disease. There were, however, a number of notable exceptions. Ludwig Grünwald (1863-1927) of Munich published Die Lehre von den Naseneiterungen (Textbook on Nasal Suppuration) in 1893 [247]. It established the subject of sinus disease on a secure foundation. $\mathrm{He}$ described an intranasal approach to the ethmoid sinuses, having first prepared the nose with cocaine. His design of forceps is still in use. Ludwig Grünwald classified ethmoid infection into a "closed type," accessible via the intranasal route, or an "open type," where the infection had spread to involve the orbit or frontal sinus, which required an external operation. Bernhard Moritz Karl Ludwig
Riedel (1846-1916) from Jena indicated, in a supervised thesis by his pupil Heinrich Schenke (1868-1935) in 1898 [248], a radical frontal sinus operation from the outside with removal of the facial and orbital sinus wall, which led to considerable disfigurement of the face. It was indicated only if the sinus was very small and narrow, and later named "Riedel's operation" or "Riedel procedure" [249].

Various modifications of sinus surgery were made, mainly related to the formation of an intranasal opening and transplantation of mucosal flap into the antrum, as suggested by Georg Boenninghaus (1860-1945) of Breslau and Alfred Denker (1863-1941) of Munich [250]. Hermann Kuhnt (1850-1925) of Jena, Königsberg, and Bonn, aimed to remove the whole of the anterior wall of the sinus and obliterated it by allowing the skin to sink into it [251]. This produced an unsightly deformity. An even greater deformity resulted from the procedure suggested by Georg Limburg in Jena, in which the inferior and anterior walls were removed [252]. In an effort to avoid this, Gustav Killian in 1900 described an incision through the eyebrow and preservation of the supraorbital bridge [253]. He achieved a complete exposure of the frontal sinus and by prolonging the incision inferiorly he was also able to remove the ethmoid air cells, thus overcoming one of the shortcomings of the Ogston-Luc procedure. Albert Jansen (1859-1933) of Berlin in 1902 [254] proposed removal of the frontal sinus floor and preservation of the anterior wall with exenteration of the adjoining ethmosphenoid system.

The osteoplastic flap operation [255] was originally described by Karl Wilhelm Schönborn (1840-1906) of Würzburg in 1894 [256], Oskar Brieger (1864-1914) of Breslau in 1895 [257] and Ernst Winckler (1860-1916) [258] of Bremen in 1904 [259]. In 1911, Gustav Spiess (1862-1948) of Frankfurt described 


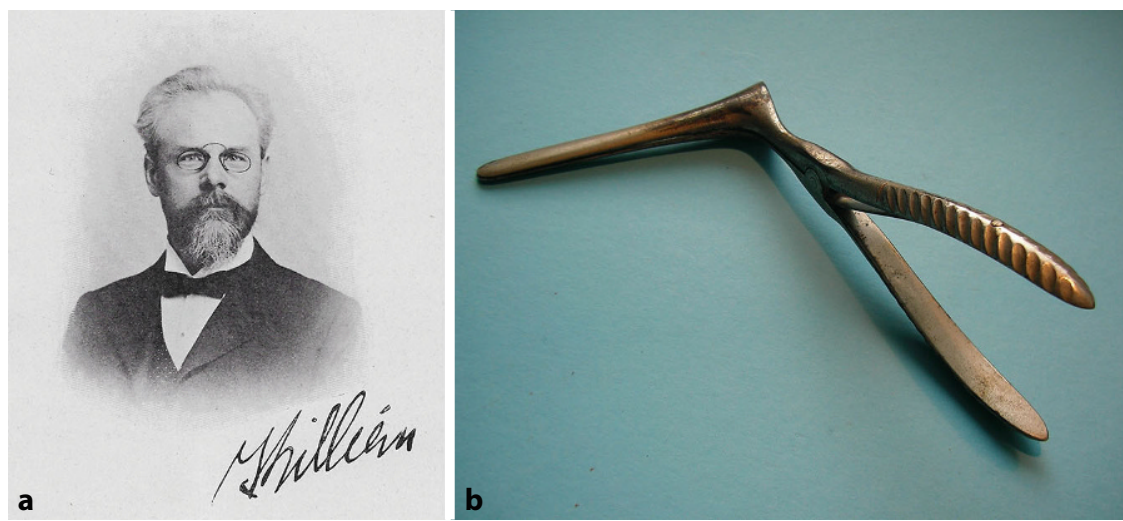

Fig. $12 \Delta$ a Gustav Killian. (From Moure 1908, [282]). b Gustav Killian's nasal speculum. (Personal collection, Dr. Lübbers. Reprinted with permission $\odot$ W. Lübbers, Hannover, all rights reserved)

a transeptal approach to the pituitary gland [260]. Gustav Killian was also very active in nasal surgery (• Fig. 12). In 1876, Bernard Fränkel (1836-1911) from Berlin wrote one of the first German chapters dealing exclusively with rhinology [261]. In 1888, Rudolf Voltolini published Die Krankheiten der Nase und des Nasenrachenraumes (The Diseases of the Nose and Rhinopharynx; [262]), which became a very popular textbook in Germany. A few years later Carl Zarniko (1863-1933) in Hamburg published another textbook Die Krankheiten der Nase (The Diseases of the Nose; [263]).

Compared with otology and laryngology, rhinology was considered to be the "poor relative" of otorhinolaryngology in the nineteenth century. No specific rhinology clinics were recognized, and nearly no academic lecturer positions in rhinology were distributed. Nevertheless, rhinology saw an important development in Germany in the second part of the nineteenth century, notably, its surgical part.

\section{Creation of ORL specialty in the 20th century}

\section{Foundation of ORL structures}

The creation of the specialty of ORL was the amalgamation of otology, laryngology, and rhinology. It was marked by the foundation of the first ORL hospital departments and university lectures and chairs, the organization of the first specific national and international conferences, and the publication of the first
ORL journals and books. It is outside the scope of this manuscript to go into too many details, but one aspect will be discussed here, i.e., the foundation of the first academic structures. Concerning books, it is worth mentioning that the German ORL textbooks appeared at the turn of the twentieth century. One of the first, in 1901, was Anleitung zur Diagnose und Therapie der Kehlkopf-, Nasen-, und Ohrenkrankheiten (Guide to the Diagnosis and Therapy of Diseases of the Lar$y n x$, Nose, and Ear), by Richard Kayser (1854-?) from Breslau [264], the 16th edition being published in 1928. Interestingly, in 1909 Otto Körner published a second-edition textbook, Lehrbuch der Ohren, Nasen- und Kehlkopf-Krankheiten (Textbook of Diseases of the Ear, Nose and Throat; [265]). The first edition deals only with otology [266]. It is a good example of this amalgamation. The first German ORL-specific instrument catalogues were found at the same time, notably the Windler in 1893 [267] and Détert in 1901 [268], both in Berlin. Many instruments were eponymously named notably after Arthur Hartmann, Anton von Tröltsch, August Lucae, Bernhard Fränkel, Rudolf Voltolini, Hermann Krause, Berhard von Langenbeck, and Hugo Beckmann, to mention a few. New companies, such as Fischer in Freiburg im Breisgau and Pflau, again in Berlin, completed the list.

\section{Academic associations}

As in many countries, there was not a linear route leading to the creation of the

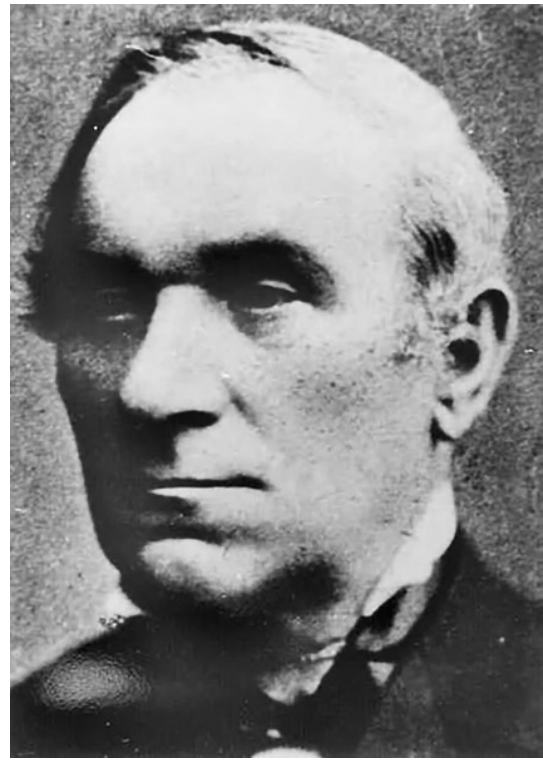

Fig. 13 ॥ Rudolf Voltolini. (From [283])

ORL specialty. It began with some solitary spots, which progressively came into contact through meetings and local societies. In 1860, Rudolf Voltolini in Breslau (- Fig. 13) obtained his PD in otology and laryngoscopy, the first of its kind in Germany. Eight years later, he was promoted to extraordinary professor for otology and laryngoscopy by the Breslau Medical Faculty [269, 270]. Interestingly, his main publications dealt with rhinology. At the same time, otology started becoming a solid specialty with the promotions of many PDs in the 1860s. Laryngology was academically not so advanced, with the same thing happening only two decades later. Thus, the official academic association of otology with laryngology had to wait more than two decades to be seen again: This occurred at Rostock University, in 1883, with Johann Christian Lemcke (1850-1894). In 1884, he moved his activities to private practice. He received his PD in otology and laryngology in 1885 and from 1889 he had a room in the university polyclinic. In recognition of his achievements, Lemcke's practice became "University Polyclinic for Ear, Nose and Throat Diseases" in 1891 [271]. Only as associate professor in $1893 \mathrm{did}$ he receive financial support, but he died 1 year later. His successor Otto Körner went a step further, becoming extraordinary professor in ORL in 1894, which, from the beginning, was salaried by the 
Hier steht eine Anzeige.

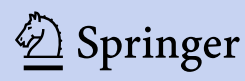



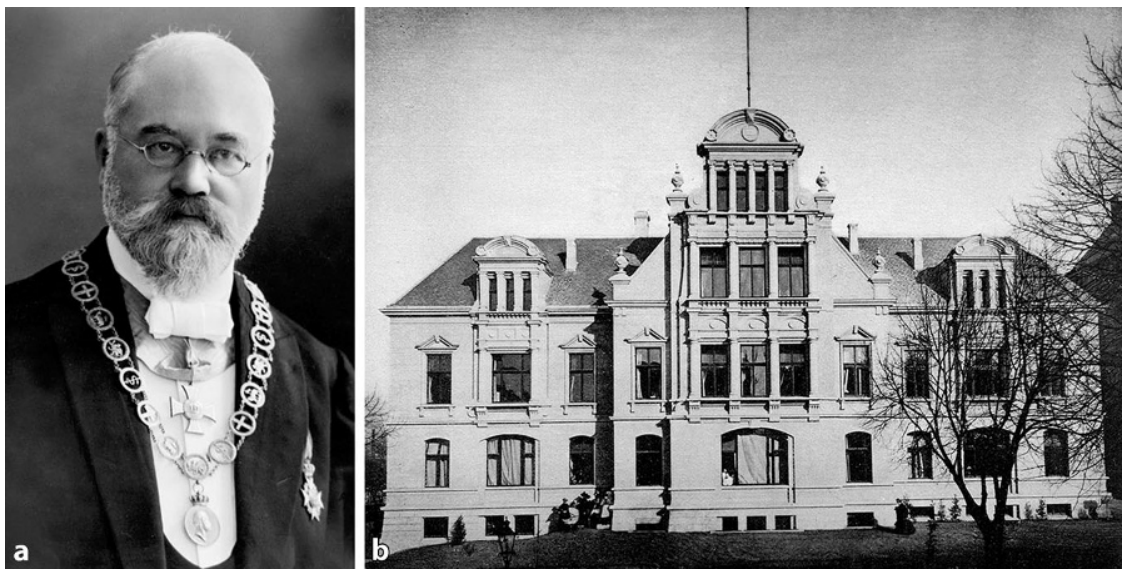

Fig. $14 \Delta$ a Otto Körner as Rector magnificus 1913/14 of the University of Rostock. (Reprinted with permission @ University of Rostock, all rights reserved). b the first ORL clinic in Rostock 1899. (From [284], reprinted with permission $\odot$ ORLclinic, University of Rostock, all rights reserved)

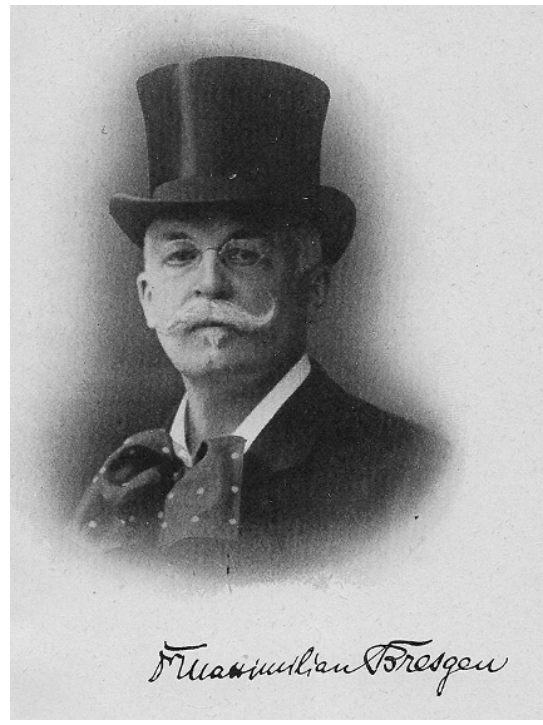

Fig. $15 \Delta$ Maximilian Bresgen. (From Moure 1908 [282])

science. In the beginning, they were separate, but it was an inevitable sideeffect of their further development that they came closer to one another $[\ldots]$ Rhinology and pharyngology served as their connecting links. There is not one otologist or laryngologist who can accomplish much of note without being as well versed in both of these disciplines as he is in his own field of specialization." $\mathrm{He}$ also mentioned the power struggle within faculties: "If one calmly considers this matter, one must concede that faculties are correct in their opinion that ophthalmology, otology, laryngology and dermatology should not possess as much significance as the main disciplines." In his opinion, an amalgamation of the study of medicine was a worthy aim and further fragmentation posed a threat to the development of such study.

Hermann Schwartze and Gustav Killian were notable opponents. Hermann Schwartze presented his opposition in discussing a lecture by Johann Ambrosius Barth (1852-1936) held in Leipzig in 1899 for his new position as director of the new clinic and polyclinic for ORL [276]: "I am convinced that otology, as well as ophthalmology, must be taught and worked as an independent discipline at the universities, if it is to prosper. Already now it does not grow up to such an extent that it needs the undivided power and time of an individual to 


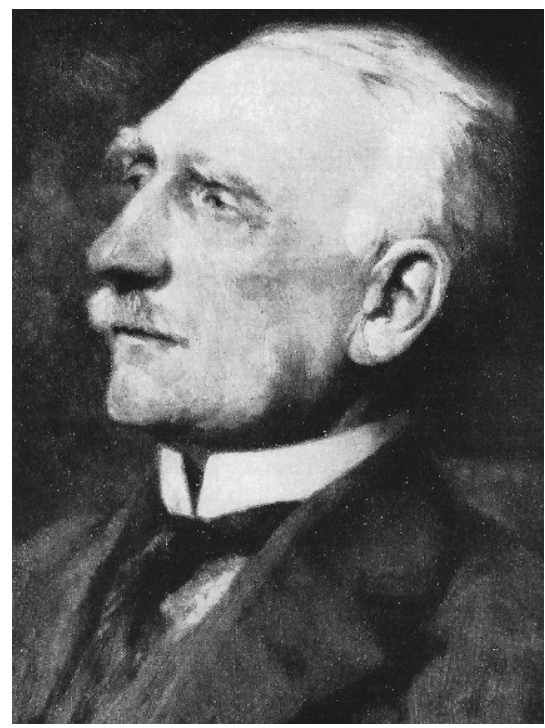

Fig. $16 \Delta$ Adolf Passow. (From Kindler, 1956 [16])

represent it exhaustively. But on the other hand, it offers to be represented exhaustively; however, it offers such problems and tasks to be solved that the connection with a discipline like laryngology, which has no contact at all with otology, can only be a hindrance. The situation is different with rhinology, because of the multiple etiological relations of the diseases of the nose and the etiological relationships of the diseases of the nose and the ear cannot be neglected by otologists." At a meeting 2 years later, Hermann Schwartze protested against this association [277]; only August Lucae supported him [278]. Gustav Killian's arguments were predominantly based on the deterioration of treatment that he believed would assuredly follow from any process of amalgamation. He argued that the academic instructor could not be competent in either of the two specialized disciplines to the extent that was necessary for the advancement of science and teaching [30].

On November 9, 1918, both boards of the German Otological Society and the Association of German Laryngologists decided to establish the Society of German Otolaryngologists. However, this was not possible, due to the revolution just taking place in Germany. Thus, both boards met again during the meeting of natural scientists and physicians in Bad Nauheim and set May 12, 1921 as the date of foundation. The founding meeting was chaired by Georg Boenninghaus as the representative of the laryngologists. In his speech, he expressed the injustice deeply felt by many Germans with the war guilt allocations and the consequences of the Treaty of Versailles. The recently deceased Gustav Killian was particularly commemorated. He had helped to propose the unification to the laryngologists. Originally, he was a fierce opponent of a merger; however, it then applied only to his laryngology clinic in Berlin, where his otology colleague, whom he did not love, had always been pushing with force for the unification into one overall specialty, of course also at his clinic in Berlin. This behavior clearly shows the difficulties and contradictions that still existed at the time of the foundation of the Society of German Otorhinolaryngologists. This new national society was founded much later than most of the other European national societies, for instance, in France in 1882 , Spain in 1886 , Italy in 1892 , The Netherlands in 1893, or Switzerland in 1912 [31].

\section{Conclusion}

The scientific and clinical developments during the period described in this article were crucial and consequently allowed for the foundation of the German Society of Otorhinolaryngology, Head and Neck Surgery on solid ground. Germany played an important role in the development and progress of otorhinolaryngology internationally in the nineteenth century with such great contributors as Anton von Tröltsch, Hermann Schwartze, Otto Körner, Rudolf Voltolini, and Gustav Killian to mention a few.

\section{Corresponding address}

Univ.-Prof. Dr. med. Robert Mlynski Klinik und Poliklinik für Hals-NasenOhrenheilkunde, Kopf- und Halschirurgie "Otto Körner", Universitätsmedizin Rostock Doberaner Str. 137-139, 18057 Rostock, Germany

hno@med.uni-rostock.de

Acknowledgements. The Authors are grateful to Ms. Anja Lühmann for her tireless support in the preparation of the manuscript and the processing of the photographic material.

\section{Declarations}

Conflict of interest. A. Mudry, R. Mlynski, and B. Kramp declare that they have no competing interests.

For this article no studies with human participants or animals were performed by any of the authors. All studies performed were in accordance with the ethical standards indicated in each case.

Open Access. This article is licensed under a Creative Commons Attribution 4.0 International License, which permits use, sharing, adaptation, distribution and reproduction in any medium or format, as long as you give appropriate credit to the original author(s) and the source, provide a link to the Creative Commons licence, and indicate if changes were made. The images or other third party material in this article are included in the article's Creative Commons licence, unless indicated otherwise in a credit line to the material. If material is not included in the article's Creative Commons licence and your intended use is not permitted by statutory regulation or exceeds the permitted use, you will need to obtain permission directly from the copyright holder. To view a copy of this licence, visit http://creativecommons.org/licenses/by/4.0/.

\section{References}

1. Mudry A, Pirsig W, Weir N (2005) History of otorhinolaryngology (ORL) in different European countries between 1880 and 1920. J Laryngol Otol Suppl 119(30):1-2

2. Berendes J (1972) HNO - ein harmonischer Dreiklang. HNO20(1):1-5

3. Jackler RK, Mudry A (2014) Otolaryngology: "Its all Greek to me". Otolaryngol Head Neck Surg 150(3):337-341

4. Isambert $E$, Krishaber $M$, Ladreit de Lacharrière J (1875) A nos lecteurs. Ann Mal Oreille Larynx 1:1-9

5. Mudry A (2016) Some thoughts about the history of otorhinolaryngology, head and neck surgery (OHNS). Hist Otorhinolaryngol 1:59-79

6. Mudry A (2015) Petite introduction à l'histoire de l'otorhinolaryngologie et chirurgie cervico-faciale (ORL). Hist Sci Med 49(3/4):355-366

7. Mudry A (2015) How to set up a library on the history of otorhinolaryngology, head \& neck surgery (OHNS). Hist Otorhinolaryngol 1:1-7

8. Lübbers W, Lübbers CW (2021) Geschichte ist das Fundament der Zukunft - Bücher als Quellen zur Geschichte der Hals-Nasen-Ohrenheilkunde. HNO Inf 46(1):7-9

9. Bernards M (1989) Geschichte der Hals-NasenOhrenheilkunde (Rhinologie und Laryngologie). Thesis, Köln

10. Feldmann H (2003) Bilder aus der Geschichte der Hals-Nasen-Ohren Heilkunde. Median, Heidelberg

11. Eulner HH (1970) Die Entwicklung der medizinischen Spezialfächer an den Universitäten des deutschen Sprachgebietes. Enke, Stuttgart, pp 347-386

12. Körner $O$ (1902) Die Vertretung der Ohrenheilkunde an den Universitäten des Deutschen Reiches in den Jahren 1878 und 1902. Z Ohrenheilkd 41:244-246 


\section{Leitthema}

13. Stern L (1913) Deutschland. In: Politzer A (ed) Geschichte der Ohrenheilkunde, vol II. Enke, Stuttgart, pp 244-286

14. Fleischer K, Naumann HH (1996) Akademische Lehrstätten und Lehrer der Oto-Rhino-Laryngologie in Deutschland im 20. Jahrhundert. Springer, Berlin

15. Brusis T (2002) Geschichte der deutschen HalsNasen-Ohren-Kliniken im 20. Jahrhundert. Springer, Berlin

16. Kindler W (1956) Die Geschichte der Oto-RhinoLaryngologie in Berlin. Thieme, Stuttgart, pp 51-57

17. Gosepath HJ (1957) Die Geschichte der HalsNasen-Ohrenheilkunde in München. Thesis. UniDruck, München, pp 2-3

18. Von Deuster C, Ptok M (1986) Zur Geschichte der Hals-Nasen-Ohrenheilkunde, insbesondere in Würzburg. Wellm, Pattensen (Hannover)

19. Thomas K (1986) Die Geschichte der Hals-, Nasen-, Ohrenklinik der Universität Düsseldorf. Triltsch, Düsseldorf

20. Pellnitz K (1900) Die Hals-Nasen-Ohrenklinik im Universitätsklinikum Rudolf Virchow - Standort Wedding. Thesis, Berlin

21. Kramp B (1999) 100 Jahre Universitäts-HNO-Klinik und Poliklinik Rostock. Oehmke, Rostock

22. Königsberger L (1902-1903) Hermann von Helmholtz. Vieweg, Braunschweig (3 vols)

23. Killian H (1958) Gustav Killian, sein Leben, sein Werk. Dustri, Remscheid

24. Nakosteen JA (2009) Gustav Killian und Shigeto Ikeda: Die Väter der Bronchoskopie. Springer, Hamburg

25. Wahler R (1981) Der Westphalische Landarzt Friedrich Hofmann als Erfinder des Ohrenspiegels. Thesis, Würzburg

26. Baudach R (1999) Anton Friedrich Freiherr von Tröltsch Begründer der modernen Ohrenheilkunde auf dem europäischen Festland. Königshausen \& Neumann, Würzburg

27. Kramp B, Jerecinski A (2010) Otto Körner Arzt, Hochschullehrer und Forscher. Oehmke, Rostock

28. Körner O (1920) Erinnerungen eines deutschen Arztes und Hochschullehrers 1858-1914. Bergmann, München \& Wiesbaden

29. Hoffmann R, Löbe LP, Pfeiffer W (2015) Ich holte meine Prager Schriften. TUDpress, Dresden

30. Hofmann O, Brusis T (2005) On the origins of the first German otorhinolaryngology (ORL) clinics. JLaryngol Otol 118(30(Suppl)):41-44

31. Weir N, Mudry A (2013) Otorhinolaryngology: an illustrated history, 2nd edn. Hedley, Asford, p 242

32. Joubert $L$ (1579) La grande chirurgie de Guy de Chauliac. Michel, Lyon, p 530

33. Cassebohm JF (1735) Tractatus quintus anatomicus de aure humana, cui accedit tractatus sextus de aure monstri humani. Orphanotrophaeus, Halae Magdeburgicae

34. Meckel PFT (1777) De labyrinthi auris contenti. Heitz, Argentorati

35. Vogel PH (1952) Innervation of the larynx. Thesis. Loyola University, Chicago

36. Andersch CS (1797) Tractatio anatomico-physiologica de nervis humani corporis aliquibus. Ed. Andersch EP. 2 vols. Fasch, Regiomonti

37. Hildanus F (1624)Anatomiae praestantia et utilitas Das ist kurtze Beschreibung der Fuertrefflichkeit, Nutz und Notwendigkeit der Anatomy. Stuber, Bern

38. Hildanus F (1641) Obserationum et curationum chirurgicarum centuriae in duo volumina distributae. Huguetan, Lugduni
39. Mudry A (2006) References in the history of otology: the importance of being earnest. Otol Neurotol 28:135-140

40. Schneider KV (1661) Liber de catarrhis tertius. Mevius \& Schumacher, Wittenbergae, p 159 (Fig. II)

41. Zuckerkandl E (1893) Normale und pathologische Anatomie der Nasenhöhle, 2nd edn. Braumüller Wien, $\mathrm{p} 1$

42. Schelhammer GC (1684) De auditu liber unus. de Graaf, Lugduni Batavorum, p 90, 259

43. Arnemann J (1792) Bemerkungen über die Durchbohrung des Processus mastoideus in gewissen Fällen der Taubheit. Vandenheock \& Ruprecht, Göttingen

44. Bretonneau PF (1826) Des inflammations spéciales du tissu muqueux et en particulier de la diphtérite, ou inflammation pelliculaire. Crevot, Paris

45. Quelmaltz ST (1750) De narium earumque septi incurvatione. Langenheim, Lipsiae

46. Heister $L$ (1719) Chirurgie in welcher alles was zur Wund-Artzney gehöret, abgehandelt und vorgestellet wird. Hoffmann, Nürnberg, pp 511-519

47. Runge LH (1750) De morbis pracipuis sinuum ossis frontis et maxillae superioris et quibusdam mandibulae inferioris. Enax, Rintelii

48. Stoetzner HE (1870) Samuel Heinicke, sein Leben und Wirken. Klinkhardt, Leipzig

49. Mudry A (2001) Naissance de l'otologie illustrée par des textes de l'époque. Ann Otolaryngol Chir Cervicofac 118:339-343

50. Wildberg CFW (1795) Versuch einer anatomischphysiologisch-pathologischen Abhandlung über die Gehörwerkzeuge des Menschen. Christ, Hein, Cuno's \& Erben, Jena

51. Mudry A (2012) Naissance des premiers journaux d'ORL au XIXe siècle. Ann Otolaryngol Pathol Cervicofac 128:261-265

52. Jelinek E (1884) Das Cocain als Anästheticum und Analgeticum für den Pharynx und Larynx. Wien Med Wochenschr 34:1334-1337, 1364-1367

53. O'Dwyer JP (1885) Two cases of croup treated by tubage of the glottis. NYMed J42:146-151

54. Ruhräh J (1935) Joseph O'Dwyer 1841-1898. Note on the history of intubation. Am J Dis Child 50(4):998-1002

55. Mudry A (2015) The history of otology. A tribute to Adam Politzer. Wayenborgh, Piribebuy, pp347-492

56. Kramer W (1836) Die Erkenntniss und Heilung der Ohrenkrankheiten. Nicolai, Berlin

57. Roosa DB (1873) A practical treatise on the diseases of the ear. Wood, New York, p42

58. Lincke CG (1845) Handbuch der theoretischen und praktischen Ohrenheilkunde vol III. Enke, Leipzig, p338 (3 vols. Leipzig: Hinrichs, 1837-1845)

59. Lincke CG (1836-1841) Sammlung auserlesener Abhandlungen und Beobachtungen aus dem Gebiete der Ohrenheilkunde. 5 vols. Hinrichs, Leipzig

60. Kramer W (1849) Die Erkentniss und Heilung der Ohrenkrankheiten, 2nd edn. Nicolai, Berlin, p32

61. Wilde W (1844) Some observations on the early history of aural surgery and the nosological arrangement of diseases of the ear. Dublin J Med Sci 25(3):422-454 (p.443)

62. Frank M (1845) Praktische Anleitung zur Erkenntniss und Behandlung der Ohrenkrankheiten. Enke, Erlangen, p310

63. Mudry A (2013) The tympanostomy tube: an ingenious invention of the mid 19th century. Int J Pediatr Otorhinolaryngol 77:153-157

64. Soemmerring ST (1778) De basi encephali et originibus nervorum cranio egredentium libri quinque. Vandenhoeck \& Ruprecht, Goettingae, pp 145-158

65. Soemmerring ST (1806) Abbildungen des menschlichen Hoerorganes. Varrentrapp \& Wenner, Frankfurt

66. Rosenthal F (1823) Ueber den Bau der Spindel im menschlichen Ohr. Dtsch Arch Physiol 8:74-78, 210

67. ArnoldF (1829) Einige neurologische Beobachtungen. ZPhysiol 3:147-151

68. Arnold F (1831) Der Kopftheil des vegetativen Nervensystems beim Menschen. Groos, Heidelberg \& Leipzig, p 108

69. Bloustine S, Langston L, Miller T (1976) Earcough (Arnold's) reflex. Ann Otol Rhinol Laryngol 85:406-407

70. Huschke E (1835) Ueber die Gehörzähne, einen eigenthümlichen Apparat in der Schnecke des Vogelohres. Arch Anat Physiol 2:335-346

71. Mudry A (2001) The origin of eponyms used in cochlear anatomy. Otol Neurotol 22:258-263

72. Huschke E, Soemmerring ST (1844) Vom Baue des menschlichen Körpers vol V. Voss, Leipzig, p 896

73. Pirsig W, Mudry A (2015) Huschke's anterior external auditory canal foramen: art before medicine? Otol Neurotol 36(3):555-560

74. Corti A (1851) Recherches sur l'organe de l'ouïe des mammifères. Première partie : limaçon. Z Wiss Zool 3:109-169

75. Kölliker A (1852) Mikroskopische Anatomie oder Gewebelehre des Menschen vol II. Engelmann, Leipzig, pp 737-763

76. Deiters O (1860) Untersuchungen über die Lamina spiralis membranacea. Henry, Cohen, Bonn

77. HelmholtzH(1863)DieLehrevon den Tonempfindungen, als physiologische Grundlage für die Theorie der Musik. Vieweg, Braunschweig

78. Helmholtz H (1869) Die Mechanik der Gehörknöchelchen und des Trommelfells. Cohen, Bonn

79. Flourens $P(1842)$ Recherches expérimentales sur les propriétés et les fonctions du système nerveux dans les animaux vertébrés, 2nd edn. Baillière, Paris, pp 438-482

80. Menière $P$ (1861) Mémoire sur des lésions de l'oreille interne donnant lieu à des symptômes de congestion cérébrale apoplectiforme. Gaz Méd Paris 21(sept):597-601

81. GoltzF (1870) Über die physiologische Bedeutung der Bogengänge des Ohrlabyrinthes. Arch Gesammte Physiol 3:172-192

82. Mach E (1873) Physikalische Versuche über den Gleichgewichtssinn des Menschen. Sitzungsber Akad Wiss Wien Math Naturwiss KI 68(3):124-140

83. Breuer J (1874) Über die Function der Bogengänge des Ohrlabyrinthes. Wien Med Jahrb 4:72-124

84. Jongkees LB (1966) J. R. Ewald. Arch Otolaryngol 83(6):615-619

85. Ewald J (1892) Physiologische Untersuchungen über das Endorgan des Nervus octavus. Bergmann Wiesbaden, pp 259-266

86. Fechner GT (1860) Elemente der Psychophysik. Breitkopf \& Härtel, Leipzig

87. Soldati D, Mudry A (2001) Knowledge about cholesteatoma, from the first description to the modern histopathology. Otol Neurotol 22:723-730

88. Mudry A (2006) Adam Politzer (1835-1920) and the description of otosclerosis. Otol Neurotol 27(2):276-281

89. Müller J (1838) Ueber den feineren Bau und die formen der krankhaften Geschwülste. Reimer, Berlin, pp 49-54 
90. Virchow R (1855) Ueber Perlgeschwulste. Arch Anat Physiol Klin Med 8:371-418

91. Bezold F (1889) Cholesteatom, Perforation der Membrana Flaccida Schrapnelli und Tubenverschluss: eine ätiologische Studie. Z Ohrenheilkd 20:5-28

92. Pappenheim SM (1840) Die specielle Gewebelehre des Gehörorganes nach Structur, Entwicklung und Krankheit. Aderholtz, Breslau, p 145

93. Hofmann F (1841) Beitrag zur Untersuchung des äussern Gehörganges. Wochenschr Ges Heilkd 4:10-14

94. Mudry A, von Deuster C, Peinhardt J (2016) Some unpublished documents and unusual portraits of Anton von Tröltsch (1828-1890), one of the founders of this journal. Eur Arch Otorhinolaryngol 273(5):1347-1355

95. Tröltsch A (1860) Die Untersuchung des Gehörorgans und Trommelfells. Ihre Bedeutung. Kritik der bisherigen Untersuchungsmethoden und Angabe einer Neuen. Dtsch Klin 12:113-115 (1860;13:121-123, 1860;14:131-135 1860;15:143-146 and 1860;16:151-154)

96. Mudry A (2015) What generated the creation of the Archiv für Ohrenheilkunde the predecessor of this journal, 150 years ago? Eur Arch Otorhinolaryngol 272(6):1341-1346

97. Brockhaus (1873) Supplement zur elften Auflage des Conversations-Lexikon vol II. Brockhaus, Leipzig, p 634

98. Tröltsch A (1862) Die Krankheiten des Ohres. Stahel, Würzburg

99. Tröltsch A (1880) Krankheiten des Gehörorgan im Kindesalter. In: Gerhardt (ed) Handbuch der Kinderkrankheiten, vol V. Laupp, Tübingen, pp 61-200 (Chap. 2)

100. Siegle E (1864) Der pneumatische Ohrtrichter, ein neues Instrument zur Untersuchung des Trommelfells. Dtsch Klin 16:363-364

101. Chladni EF (1787) Entdeckungen über die Theorie des Klanges. Weidmann, Leipzig

102. Chladni EF (1802) Die Akustik. Breitkopf \& Härtel, Leipzig

103. Weber EH (1834) De pulsu, resorptione, auditu et tactu. Koehler, Lipsiae, pp 41-42

104. Rinne A (1855) Beiträge zur Physiologie des menschlichen Ohres. Vierteljahrschr Prakt Heilkd 45:71-123 (and 1855:46:45-72)

105. Lucae A (1880) Besprechungen. V. Hensen. Physiologie des Gehörs. Arch Ohrenheilkd 16:86-100

106. Bezold F (1888) Statistische Ergebnisse über die diagnostische Verwendbarkeit des Rinne'schen Versuches und eine daraus sich ergebende Erklärung für die physiologische Funktion des Schalleitungsapparates. Z Ohrenheilkd 17:153-237

107. Bezold F (1889) Zweiter Nachtrag zu den Stimmgabeluntersuchungen. Z Ohrenheilkd 19:212-230

108. Mion M, Martini A, Mudry A (2020) Hearing balance and communication jubilees exponents of the "twenties": Dagobert Schwabach (1846-1920) and his tuning fork test. Hear Balance Commun 18(3):210-214

109. Wolke CH (1802) Nachricht von den zu Jever durch die Galvani-Voltaische Gehör-Gebe-Kunst beglückten Taubstummen. Schulzer, Oldenburg

110. Polansky F (1842) Grundriss zu einer Lehre von den Ohrenkrankheiten. Beck, Wien, p72

111. Hartmann A (1878) Eine neue Methode der Hörprüfung mit Hülfe elektrischer Ströme. Arch AnatPhysiol:155-157
112. Feldmann H(1960)DiegeschichtlicheEntwicklung der Hörprüfungsmethoden. Thieme, Stuttgart, p28

113. Hartmann A (1881) Die Krankheiten des Ohres und deren Behandlung. Fischer, Berlin

114. Kretschmann F (1910) Hermann Schwartze 7 September 1837-20. August 1910. Arch Ohrenheilkd 83:I-XVI

115. Schwartze H, Eysell A (1873) Ueber die künstliche Eröffnung des Warzenfortsatzes. Arch Ohrenheilkd 7:157-187

116. Mudry A (2009) History of instruments used for mastoidectomy. J Laryngol Otol 123:583-589

117. Küster E (1889) Ueber die Grundsätze der Behandlung von Eiterungen in starrwandigen Höhlen, mit besonderer Berücksichtigung des Empyems der Pleura. Dtsch Med Wochenschr 15(10):185-187(15(11):213-215, 15(12):233-236, 15(13):254-257)

118. Bergmann $E$ (1890) Surgical treatment of diseases of the brain. Gryphon, New York, pp 866-867 (Reprint 1994)

119. Stacke L (1890) Indicationen, betreffend die Excision von Hammer und Amboss. Arch Ohrenheilkd 31:201-215

120. Kessel J (1876) Ueber die Durchschneidung des Steigbügelmuskels beim Menschen und über die Extraction des Steigbügels, resp. der Columella be Thieren. Arch Ohrenheilkd 11:199-217

121. Kessel J (1878) Ueber das Mobilisiren des Steigbügels durch Ausschneiden des Trommelfelles, Hammers und Ambosses bei Undurchgängigkeit derTuba. Arch Ohrenheilkd 13:69-88

122. Heermann H (1969) Johannes Kessel and the history of endaural surgery. Arch Otolaryngol 90:136-142

123. Kessel J (1887) Ueber die Behandlung der chronischen eitrigen Mittelohrentzundungen. Corresp Allg Arztl Ver Thüringen 16(9):359-373

124. Lucae A (1884) Ueber eine Methode zur mechanischen Behandlung der chronischen Beweglichkeitsstörungen imschallleitenden Apparat des Gehörorgans. Arch Ohrenheilkd 21:84-91

125. Tange RA, Mudry A (2017) Lucae's springy pressure probe to mobilize the ossicular chain: rise and fall of an ingenious instrument. Otol Neurotol 38:454-459

126. Hühnermann T (1959) Zur Erinnerung an Adolf Passow. ZLaryngol Rhinol Otol 38:655-657

127. Passow KA (1897) Diskussion. VerhandI Dtsch Oto Ges 6:143-144

128. Mudry A (2008) History of myringoplasty and tympanoplasty type I. Otolaryngol Head Neck Surg 139:613-614

129. Berthold E (1878) Ueber Myringoplastik. Wien Med Blätter 26:627-630

130. Berthold E (1889) Die ersten zehn Jahre der Myringoplastik nebst Angaben verbesserter Methoden zur Heilung von alten Löchern im Trommelfell. Hirschwald, Berlin

131. Henneberg $R$, Koch $M$ (1902) Über centrale Neurofibromatose und die Geschwülste des Kleinhirnbrückenwinkels (Acusticusneurome). Arch Psychiatr 36:251-304

132. Cushing $\mathrm{H}$ (1917) Tumors of the nervus acusticus and the syndrome of the cerebellopontine angle. Saunders, Philadelphia \& London, pp 10-13

133. Krause $F$ (1903) Zur Freilegung der hinteren Felsenbeinfläche und des Kleinhirns. Beitr Klin Chir 37:728-764

134. Panse R (1904) Ein Glioms des Akusticus. Arch Ohrenheilkd 61:251-255
135. Kessel J (1901) Rede zur feierlichen Eröffnung der neuen Universitäts-Ohrenklinik in Jena am 14. December 1900. Arch Ohrenheilkd 51:177-186

136. Rötz T (2012) Georg Edmund Dann (1898-1979) Leben und Werk eines Pharmaziehistorikers im 20. Jahrhundert. Thesis, Marburg (Lahn), p 13

137. Politzer A (1896) Nekrolog. Prof. S. Moos. Arch Ohrenheilkd 40:25-30

138. Tröltsch A (1878) Vorstellung beim Reichskanzleramte, betreffend die Berücksichtigung der Ohrenheilkunde bei Festsetzung der neuen Vorschriften für die ärztliche Schlussprüfung. Arch Ohrenheilkd 14:151-164

139. Tröltsch A (1883) Gesammelte Beiträge zur pathologischen Anatomie des Ohres und zur Geschichte der Ohrenheilkunde. Vogel, Leipzig, pp 247-249

140. No author (1895) Stattuten der deutschen otologischen Gesellschaft. Verh Dtsch Otol Gesell 1:vii-xv

141. No author (1968) History of the American otological society, Inc. 1868-1968. American otological society, Syracuse, N.Y.

142. Holmes $G$ (1887) Die Geschichte der Laryngologie von den frühesten Zeiten bis zur Gegenwart. Hirschwald, Berlin

143. Feldmann H (2002) Die Diagnostik und Therapie der Kehlkopfkrankheiten in der Geschichte der Medizin. Teil III: Nach der Erfindung der indirekten Laryngoskopie. Laryngol Rhinol Otol 81:596-604

144. Mende LJC (1816) Von den Bewegung der Stimmritze beym Athemholen. Dyk, Greifswald

145. Lehfeldt C (1835) Nonnulla de vocis formatione. Nietackianis, Berolini, pp 64-66

146. Kölliker A (1852) Handbuch der Gewebelehre des Menschen. Engelmann, Leipzig, pp 361-363

147. Henle J (1866) Handbuch der Eingeweidelehre des Menschen. Vieweg, Braunschweig, pp 144-146

148. Henle J (1838) Ueber die Ausbreitung des Epithelium im menschlichen Körper. Arch Anat Physiol:103-128

149. Amene C, Cosetti M, Ambekar S et al (2013) Johann Christian Rosenmüller (1771-1820): a historical perspective on the man behind the fossa. J Neurol Surg B Skull Base 74(4):187-193

150. Rosenmüller C (1805) Chirurgisch-Anatomische Abbildungen vol I. Landes-Industrie Comptoirs, Weimar, pp 11-12 (Taf. 3\&4)

151. Rosenmüller C (1816) De nervorum olfactorium defectu. Lipsiae

152. Waldeyer HWG (1884) Ueber den lymphatischen Apparat des Pharynx. Dtsch Med Wochenschr 10:313

153. Tubbs RS, Vahedi $P$, Loukas M et al (2011) Hubert von Luschka (1820-1875): his life, discoveries, and contributions to our understanding of the nervous system. J Neurosurg 114:268-272

154. von Luschka H (1868) Der Schlundkopf des Menschen. Laupp, Tübingen

155. BurnettC (1893) System of diseases of the ear, nose, and throat vol I. Lippincott, Philadelphia, p 573

156. Tornwaldt $L$ (1885) Ueber die Bedeutung der Bursa pharyngea für die Erkennung und Behandlung gewisser Nasenrachenraum Krankheiten. Bergmann, Wiesbaden

157. Miller RH, Sneed WF (1985) Tornwaldt's bursa. Clin Otolaryngol 10:21-25

158. Mayer AFCJ (1840) Bursa seu cystis tubae Eustachianae bei einigen Säugethieren. Froriep's Neue Not Geb Nat Heilkd 14(287):1-2

159. Albers JFH (1829) Die Pathologie und Therapie der Kehlkopfskrankheiten. Cnobloch, Leipzig

160. Ludwig W (1837) Ueber eine neue Art von Halsentzündung. Schmidt's Jahrb 15:25-27 
161. Wasson J, Hopkins C, Bowdler D (2006) Did Ludwig's angina kill Ludwig? J Laryngol Otol 120(5):363-365

162. Bozzoni $P$ (1806) Lichtleiter, eine Erfindung zur Anschaung innerer Theile und Krankheiten nebst der Abbildung. Practischen Arzneykd Wundarzneykunst 24:107-124

163. Bush RB, Leonhardt A, Bush I, Landes R (1974) Dr. Bozzini's Lichtleiter. A translation of his original article (1806). Urology 3:118-123

164. Kussmaul A (1869) Ueber die Behandlung der Magenerweiterung durch eine neue Methode mittelst der Magenpumpe. Poppen, Freiburg

165. Killian G (1901) Zur Geschichte der Oesophago und Gastroskopie. Dtsch ZChir 58:499-512

166. Kluge F, Seidler E (1986) Zur Erstanwendung der Ösophago- und Gastroskopie. Briefe von Adolf Kussmaul und seinen Mitarbeitern. Med Hist J 21:288-307

167. Brusis T, Luckhaupt H (1991) Zur Geschichte der Oesophagoskopie. Laryngorhinootologie 70(2):105-108

168. Waldenburg L (1870) Oesophagoskopie. Eine neue Untersuchungsmethode. Berl Klin Wochenschr 48:578-580

169. Schlemmer F (1929) Oesophagoskopie. In: Denker A, Kahler O (eds) Handbuch der HalsNasen-Ohren-Heilkunde, vol IX. Springer \& Bergmann, Berlin \& München, pp 36-79

170. Hirsch NP, Smith GB, Hirsch PO (1986) Alfred Kirstein pioneer of direct laryngoscopy. Anaesthesia 41:42-45

171. Kirstein A (1895) Autoskopie des Larynx und Trachea (Laryngoscopia directa, Euthyskopie, Besichtigung ohne Spiegel). Arch Laryngol Rhinol 3:156-164

172. Kirstein A (1896) Die Autoscopie des Kehlkopfes und der Luftröhre. Koblenz, Berlin

173. Killian G (1898) Ueber direkte Bronchoskopie. München Med Wochenschr 45:844-847

174. Killian G (1911) Zur Geschichte der Bronchoskopie und Oesophagoskopie. Dtsch Med Wochenschr 37:1585-1587

175. Moore I (1926) Peroral endoscopy: an historical survey from its origin to the present day. J Laryngol Otol 41:277-298, 361-382

176. Marsch BR (1996) Historic development of bronchoesophagology. Otolaryngol Head Neck Surg 114:689-716

177. Brünings W (1910) Die direkte Laryngoskopie, Bronchoskopie und Oesophagoskopie. Bergmann Wiesbaden

178. Oertel M (1878) Laryngostroboscopische Beobachtungen über die Bildung der Register be der menschlichen Stimme. Centralbl Med Wiss 16:99-101

179. Oertel M (1895) Das Laryngo-Stroboskop und die Laryngo-Stroboskopische Untersuchung. Arch Laryngol Rhinol 3:1-16

180. Zeitels SM (1999) Universal modular glottiscope system: the evolution of a century of design and technique for direct laryngoscopy. Ann Otol Rhinol Laryngol Suppl 179:2-24

181. Herrmann G (1984) Max Joseph Oertel (1835-1897). Laryngorhinootologie 63(6):271-273

182. Physick PS (1828) Case of obstinate cough, occasioned by elongation of the uvula, in which a portion of that organ was cut off, with a description of the instrument employed for that purpose, and also for excision of scirrhous tonsils. Am JMed Sci 2:262-265
183. Trautmann G (1913) Technik der extrakapsulären Totalexstirpation der Tonsillen. Munch Med Wochenschr 60(40):2223-2226

184. Meyer HW (1870) On adenoid vegetations in the nasopharyngeal cavity. Med Chir Trans 53:191-216

185. Meyer HW (1873) Ueber adenoide Vegetationen in der Nasenrachenhöhle. Arch Ohrenheilkd 3:241-254 (1874;8:117-157,241-274)

186. Gottstein J (1886) Zur Operation der adenoiden Vegetationen im Nasenrachenraum. Berl Klin Wochenschr 23:25-26

187. Beckmann H (1897) Zur Pathologie und Therapie der Rachenmandel. Monatsschr Ohrenheilkd 31:389-401

188. Middeldorpf AT (1854) Die Galvanocaustik, ein Beitrag zur operativen Medizin. Max, Breslau

189. Bruns V (1862) Die erste Ausrottung eines Polypen in der Kehlkopfhöhle durch Zerschneiden ohne blutige Eröffnung der Luftwege. Laupp \& Siebeck Tübingen

190. Bruns V (1868) Dreiundzwanzig neue Beobachtungen von Polypen des Kehlkopfes. Laupp, Tübingen

191. SchüllerM(1880)DieTracheotomie, Laryngotomie und Exstirpation des Kehlkopfes. Enke, Stuttgart, p 197

192. Gussenbauer C (1874) Über die erste durch Theodor Billroth am Menschen ausgeführte Kehlkopf-Exstirpation und die Anwendung eines künstlichen Kehlkopfes. Langenbecks Arch Klin Chir 17:343-356

193. Langenbeck B (1875) Totalextirpation des Kehlkopfs mit dem Zungenbein einem Teil der Zunge, des Pharynx und Oesophagus. Berl Klin Wochenschr 12:453-455

194. Schwartz AW, Devine KD (1959) Some historical notes about the first laryngectomies. Laryngoscope 69(2):194-201

195. Folz BJ, Silver CE, Rinaldo A, Ferlito A (2011) Themistocles Gluck: biographic remarks emphasising his contributions to laryngectomy. Eur Arch Otorhinolaryngol 268:1175-1179

196. Gluck T, Zeller A (1881) Die prophylactische Resection der Trachea. Langenbecks Arch Klin Chir 26:427-436

197. GluckT, Soerensen J (1920) Ergebnisse einer neuen Reihe von 100 Totalexstirpationen des Kehlkopfes. Arch Laryngol 33:84-102

198. Schmid H (1889) Zur Statistik der Totalextirpation des Kehlkopfes im functionellen Sinne: Laute, verständliche Sprache. Arch Klin Chir 38:132-142

199. Hansson N, Drobietz M, Mudry A (2020) Otorhinolaryngologists nominated for the Nobel Prize 1901-1940. Eur Arch Otorhinolaryngol 277:1255-1258

200. Gottstein J (1900) Pseudostimme nach Totalextirpation des Larynx. Arch Klin Chir 62:126-146

201. Wolff J (1893) Ueber Verbesserungen am künstlichen Kehlkopf nebst Vorstellung eines Falles von totaler Kehlkopfextirpation. Arch Klin Chir 45:237-256

202. Delavan B (1941) The origin of laryngology. Ann Otol Rhinol Laryngol 50:629-632

203. Passow A (1909) Otologie und Laryngologie. Beit Anat Physiol Pathol Ther 2:250-263

204. Mackenzie JN (1885) Historical notes on the discovery of the nasal erectile tissue. Boston Med Surg J62:1

205. Kohlrausch O (1853) Ueber das Schwellgewebe an den Muscheln der Nasenschleimhaut. Arch Anat Physiol:149-150

206. Voltolini R (1859) Ein Erleuchtungsapparat zur Untersuchung kranker Ohren, auch anderer
Höhlen des menschlichen Körpers. Virchows Arch 17:193-196

207. Voltolini R (1861) Die Rhinoskopie und Pharyngoskopie. Festschrift zur 50jähr. Jubelfeier der Univesrs. Breslau. Gosohorsky, Breslau

208. Voltolini R (1879) Die Rhinoskopie und Pharyngoskopie, 2nd edn. Morgenstern, Breslau

209. Scheier M (1897) Über die Photographie der Nase und des Kehlkopfes mittles Roentgenstrahlen. Berl Klin Wochenschr 34:638-642

210. Scheier M (1897) Über die Verwertung der Roentgenstrahlen in der Rhino- und Laryngologie. Arch Laryngol 6:57-66

211. Hirschmann A (1903) Ueber Endoskopie der Nase und deren Nebenhöhlen. Arch Laryngol Rhinol 14(1):195-202

212. Hirschmann A (1903) Endoscopy of the nose and its accessory sinuses. Laryngoscope 13(10):810

213. Krause H (1888) Discussion über den Vortrag des Herrn B. Frankel: über das Empyem der Oberkieferhöhle. Verh Berl Med Ges 18:43-49

214. Chelius MJ (1845) Handbuch derChirurgie, 6thedn. vol II. Groos, Heidelberg \& Leipzig, pp 526-540 (Part. II)

215. Michel C (1876) Die Krankheiten der Nasenhöhle und des Nasenrachenraumes. Hirschwald, Berlin, p71

216. Kiesselbach W (1880) Bericht über die in der chirurgischen Poliklinik vom 1. October 1878 bis 1 October 1880 behandelten Fälle von Ohren- und Nasenkrankheiten. München Med Wochenschr 27(49):533-535

217. Kiesselbach W (1884) Ueber spontane Nasenblutungen. Berl Klin Wochenschr 21:375-377

218. Frank JP (1807) De curandis hominum morbis epitome, praelcotionibus academicis dictata. Liber V. Pars II. Schwan \& Goetz, Mannheim, p 144

219. Mackenzie M (1884) A manual of diseases of the throat and nose vol II. Blakiston, Philadelphia, p280

220. Ziem KKH (1886) Ueber Bedeutung und Behandlung der Naseneiterungen. Monatsschr Ohrenheilkd 20:33-43, 79-84, 137-147

221. Hack W (1882) Reflex neuroses. Berl Klin Wochenschr 19:379

222. Graefe CF (1818) Rhinoplastik, oder die Kunst den Verlust der Nase organisch zu ersetzen. Realschulbuchhandlung, Berlin, p59, 105

223. Dieffenbach JF (1829) Ueber eine neue und leichte Art der Wiederherstellung der eingefallen Nase aus den Trümmern der alten. Mag Gesamte Heilkd 28:105-110

224. Dieffenbach JF (1833) Surgical observations on the restoration of the nose and the removal of polypi and other tumors from the nostrils. Highley, London

225. Bünger HC (1823) Gelungener Versuch einer Nasenbildung aus einem völlig getrennten Hautstück aus dem Beine. Graefe Walter J Chir Augenheilkd 4:569-582

226. Dieffenbach JF (1845-1848) Die operative Chirurgie. Brockhaus, Leipzig (2 vols)

227. McDowell F (1978) History of rhinoplasty. Aesth Plast Surg 1:321-348

228. Walter C, Brain DJ (1993) Jacques Joseph. Facial Plast Surg 9(2):116-124

229. Joseph J (1898) Ueber die operative Verkleinerung einer Nase. Berl Klin Wochenschr 40:882-885

230. Joseph J (1931) Nasenplastik und sonstige Körperplastik. Kabitzsch, Leipzig

231. Behrbohm H, BriedigkeitW, Flemming J etal (2016) Jacques Joseph original instrument collection. Hist Otorhinolaryngol 1:85-98

232. Zeis $\mathrm{E}$ (1838) Handbuch der plastischen Chirurgie. Reimer, Berlin 
233. Zeis E (1863) Die Literatur und Geschichte der plastischen Chirurgie. Engelmann, Leipzig, pp 79-100

234. Langenbeck CJM (1834) Nosologie und Therapie der chirurgischen Krankheiten in Verbindung mit der Beschreibung der chirurgischen Operationen vol V. Dieterich, Göttingen, pp 133-134

235. Langenbeck CJM (1842) Handbuch der Anatomie vol III. Dieterich, Göttingen, p 278

236. Linhart W (1862) Compendium der chirurgischen Operationslehre. Braumüller, Wien, pp 516-517

237. Hartmann A (1882) Partielle Resektion der Nasenscheidewand. Dtsch Med Wochenschr 8:691

238. Pirsig W (1982) Septumdeviation 1882: Beginn de systematischen submukösen Septumchirurgie. Laryngol Rhinol Otol 61:547

239. Krieg R(1886) Resection der Cartilago quadrangularis septi narium zur Heilung der Scoliosis septi. Med Correspondenzbl Württ Ärztl Ver 56:201-204, 209-213

240. Krieg R (1889) Beiträge zur Resektion der Cartilago quadrangularis narium zur Heilung des Scoliosis septi. Berl Klin Wochenschr 26:699-701,717-720

241. Boenninghaus G (1899) Über die Beseitigung schwerer Verbiegungen des knorpeligen und knöchernen Nasenscheidewand durch die Resektion. Arch Laryngol Rhinol 9:269-284

242. Killian G (1904) Die submucöse Fensterresektion der Nasenscheidewand. Arch Laryngol Rhinol 16:362-387

243. Edwards N (1975) Septoplasty rational surgery of the nasal septum. J Laryngol Otol 89(9):875-897

244. Rudert H (1984) Von der submukösen Septumresektion Killians über Cottles Septumplastik zur modernen plastischen Septumkorrektur und funktionellen Septo-Rhinoplastik. HNO32(6):230-233

245. Willemot J (1990) History of rhinology: functional surgery of the nose in France at the turn of the century. Rhinology 28(4):275-280

246. Schaeffer M (1885) Chirurgische Erfahrungen in der Rhinologie und Laryngologie. Bergmann, Wiesbaden, p4

247. Grünwald L (1893) Die Lehre von den Naseneiterungen mit besonderer Rücksicht auf die Erkrankungen der Sieb und Keilbeins und deren chirurgische Behandlung. Lehmann, München \& Leipzig

248. Schenke H (1898) Ueber die Stirnhöhlen und ihre Erkrankungen. Thesis. Kämpfe, Jena

249. Hajek M (1903) Pathologie und Therapie der entzündlichen Erkrankungen der Nebenhöhlen der Nase, 2nd edn. Deuticke, Leipzig, pp 187-188

250. Denker A (1905) Zur Radikaloperation des chronischen Kieferhöhlenempyems. Arch Laryngol Rhinol 17:221-232

251. Kuhnt H (1895) Ueber die entzündlichen Erkrankungen der Stirnhöhlen. Bergmann, Wiesbaden

252. Limburg G (1898) Ueber das Empyem der Stirnhöhle. Neuenhahn, Jena

253. Killian G (1900) Die Krankheiten der Stirnhöhle. In Heymann P (ed) Handbuch der Laryngologie und Rhinologie, vol III. Holder, Wien, pp 1097-1172 (Part. II)

254. Jansen A (1902) NeueErfahrungen überchronische Nebenhöhleneiterungen. Arch Ohren Nasen Kehlkopfheilkd 56:110-112

255. Lehmann RH (1970) Frontal sinus surgery. Acta Otolaryngol 270(Suppl):1-21

256. Wittkop A (1894) Ein Beitrag zur Casuistik der Erkrankungen des Sinus frontalis. Fromme, Würzburg

257. Haug R (1895) Wissenschaftliche Rundschau. Brieger, Ueber chronische Eiterungen der Neben- höhlen der Nase und Demonstrationen zur operativen Behandlung chronischer Mittelohreiterungen. Arch Ohren Nasen Kehlkopfheilkd 39:213-214

258. Zarnico C (1916) Ernst Winckler. Nachruf. Arch Ohren Nasen Kehlkopfheilkd 100:I-VI

259. Winckler E (1904) Beitrag zur osteoplastischen Freilegung des Sinus frontalis. Verh Dtsch Otol Ges 13:128-133

260. Spiess G (1911) Tumor der Hypophysengegend auf endonasalen Wege erfolgreich operiert. München Med Wochenschr 58:2503

261. Fränkel B (1876) Krankheiten der Nase. In Ziemssen $\mathrm{H}$ (ed) Handbuch der speciellen Pathologie und Therapie, vol IV/1. Vogel, Leipzig, pp 91-168

262. Voltolini R(1888) Die Krankheiten der Nase und des Nasenrachenraumes. Morgenstern, Breslau

263. Zarniko C (1894) Die Krankheiten der Nase. Karger, Berlin

264. Kayser R (1901) Anleitung zur Diagnose und Therapie der Kehlkopf-, Nasen- und Ohrenkrankheiten. Karger, Berlin

265. Körner O (1909) Lehrbuch der Ohren-, Nasenund Kelhkopf-Krankheiten, 2nd edn. Bergmann, Wiesbaden

266. KörnerO (1906) Lehrbuch der Ohrenheilkunde und ihre Grenzgebiete. Bergmann, Wiesbaden

267. Windler H (1893) Special-Catalog von Instrumenten für Ohr, Nase, Nasen-Rachenraum, Kehlkopf und Tonsillen. Windler, Berlin

268. Détert R (1901) Instrumente für Ohr, Nase, Hals, Schlund und die Nebengebiete. Détert, Berlin

269. Gruber J (1889) Prof. Dr. Rudolf Voltolini. MonatsschrOhrenheilkd 23(10):217-223

270. Hinsberg V (1911) Klinik für Ohren-, Nasenund Halskrankheiten. In: Festschrift für Feier des hundertjährigen Bestehens der Universität Breslau. Kaufmann, Breslau, pp 326-329

271. Lemcke JC (1894) Bericht über die UniversitätspoliklinikfürOhren-Nasen-und Kehlkopfkrankheiten in Rostock vom 1. Juli 1891 bis dahin. Arch Ohrenheilkd 36:55-70

272. Körner O (1900) Die Grossherzogliche UniversitätsKlinik für Ohren- und Kehlkopfkranke zu Rostock. ZOhrenheilkd 36:145-154

273. No author (1901) Seine Hoheit Herzog Johann Albrecht Regent von Mecklenburg-Schwerin. ZOhrenheilkd 39:1

274. Bresgen M (1883) Zur Vereinigung der Otologie mit der Rhino-Laryngologie zu einem einzigen Specialfache. Dtsch Med Wochenschr 9(49):721

275. Passow A (1908) Otologie und Laryngologie, Vereinigung oder Trennung? Verh Dtsch Otol Ges 17:19-30

276. Schwartze H (1900) Besprechungen. A. Barth, Ueber den gegenwärtigen Stand der Hals-, Nasen- und Ohrenheilkunde. Arch Ohrenheilkd 48:112-118

277. Schwartze H (1902) Mein Protest gegen die Verbindung der Section für Ohrenheilkunde mit der Laryngologie auf der Versammlungen deutscher Naturforscher und Aerzte. Arch Ohrenheilkd 54:265-267

278. Meyer R (1902) 73. Versammlung deutscher Naturforscher und Aerzte in Hamburg vom 22. Bis 28. September 1901. 20. Abtheilung: Hals-, Nasenund Ohrenheilk. Arch Ohrenheilkd 54:278-290

279. Tröltsch A (1864) The diseases of the ear. Edited and translated by Roosa J. William Wood, New York

280. Dench EB (1896) Diseases of the ear. D. Appleton and company, New York

281. Reiniger-Gebbert, Schall (1905) Elektro-Med. Apparate, 9th edn. Erlangen
282. Moure EJ (1908) Galerie internationale des otorhino-laryngologistes. Gounouilhou, Bordeaux

283. https://commons.wikimedia.org/wiki/File: Rudolf_Voltolini.jpg. Accessed 17 Mar 2021

284. Deutscher Verein für Öffentliche Gesundheitspflege (1901) Festschrift der XXVI. Versammlung des Deutschen Vereins für Öffentliche Gesundheitspflege gewidmet von der Stadt Rostock. Rathsund Universitäts-Buchdruckerei von Adler's Erben Rostock 